\title{
T Helper Cell Differentiation, Heterogeneity, and Plasticity
}

\author{
Jinfang Zhu \\ Molecular and Cellular Immunoregulation Section, Laboratory of Immunology, National Institute of Allergy \\ and Infectious Diseases, National Institutes of Health, Bethesda, Maryland 20892 \\ Correspondence: jfzhu@niaid.nih.gov
}

\begin{abstract}
Naïve CD4 T cells, on activation, differentiate into distinct T helper (Th) subsets that produce lineage-specific cytokines. By producing unique sets of cytokines, effector Th subsets play critical roles in orchestrating immune responses to a variety of infections and are involved in the pathogenesis of many inflammatory diseases including autoimmunity, allergy, and asthma. The differentiation of Th cells relies on the strength of T-cell receptor (TCR) signaling and signals triggered by polarizing cytokines that activate and/or up-regulate particular transcription factors. Several lineage-specific master transcription factors dictate Th cell fates and functions. Although these master regulators cross-regulate each other, their expression can be dynamic. Sometimes, they are even coexpressed, resulting in massive Th-cell heterogeneity and plasticity. Similar regulation mediated by these master regulators is also found in innate lymphoid cells (ILCs) that are innate counterparts of Th cells.
\end{abstract}

$\mathrm{C}$ ytokines are the central mediators of immune responses, and CD4 T helper (Th) cells are the professional cytokine-producing cells. By producing effector cytokines, Th cells play critical roles during adaptive immune responses to infections; distinct Th subsets are involved in protective immunity to different pathogens (Murphy and Reiner 2002; Zhu and Paul 2008; Zhu et al. 2010). There are different types of Th cells based on their cytokine profiles. Initially, type $1 \mathrm{~T}$ helper (Th1) and type 2 $\mathrm{T}$ helper (Th2) cell clones that preferentially produce interferon $\gamma$ (IFN- $\gamma$ ) and interleukin (IL)-4, respectively, were reported (Mosmann et al. 1986; Mosmann and Coffman 1989; Paul and Seder 1994). A third major CD4 Th effector cell population Th17 that produces IL-17 was not discovered until decades later (Park et al. 2005; Acosta-Rodriguez et al. 2007; Weaver et al. 2007; Korn et al. 2009). All of the Th1, Th2, and Th17 cells are differentiated from naïve CD4 T cells when they are activated through T-cell receptor (TCR)-mediated signaling. Not only are the Th effector cells important for protective immunity, they can also induce inflammatory responses to self-antigens or to nonharmful allergens, resulting in autoimmunity or allergic diseases, respectively (Paul and Zhu 2010; Zhu et al. 2010). Interestingly, naïve $\mathrm{CD} 4 \mathrm{~T}$ cells can also develop into regulatory $\mathrm{T}$ cells (Tregs), which are important for maintaining immune tolerance and for regulating the magnitude of immune responses (Shevach 2000; Chen et al. 2003; Sakaguchi 2004; Josefowicz et al. 2012; Abbas et al. 2013).

Editors: Warren J. Leonard and Robert D. Schreiber

Additional Perspectives on Cytokines available at www.cshperspectives.org

Copyright (C) 2018 Cold Spring Harbor Laboratory Press; all rights reserved; doi: 10.1101/cshperspect.a030338

Cite this article as Cold Spring Harb Perspect Biol 2018;10:a030338 
J. Zhu

Th cells can produce the majority of the known cytokines. In addition to the signature effector cytokines, IFN- $\gamma$, IL-4, and IL-17A, Th cells may preferentially express many other important cytokines, such as lymphotoxin $\alpha$ for Th1; IL-5, IL-9, IL-13, and IL-24 for Th2; and IL-17F and IL-22 for Th17 cells. In addition, all of the Th subsets are capable of producing IL-2, IL-6, IL-10, IL-21, tumor necrosis factor $\alpha$ (TNF- $\alpha$ ), and granulocyte macrophage colonystimulating factor (GM-CSF). Furthermore, some regulatory functions of Tregs are mediated through production of anti-inflammatory cytokines such as transforming growth factor (TGF)- $\beta$, IL-10, and IL-35. Not only are Th cells professional cytokine producers, they can also respond to a variety of cytokines, including IL-1, IL-7, IL-12, IL-15, IL-18, IL-23, IL-27, IL-33, and type 1 IFNs, etc., that are produced by accessory cells. During differentiation, Th cells can also respond to their own cytokines, including IFN- $\gamma$ and IL-4, resulting in powerful positive feedback or cross-inhibitory effects.

In this review, I will mainly focus on effector Th-cell differentiation, heterogeneity, and plasticity regulated by cytokines and transcription factors. Because innate lymphoid cells ([ILCs], an innate equivalent of Th cells) are also professional cytokine-producing cells (Artis and Spits 2015), the relationships between conventional Th cells and ILCs will also be discussed.

\section{DISTINCT FUNCTIONS OF Th-CELL SUBSETS}

Different Th-cell subsets have distinct immune functions in protective immunity. Th1 cells (Szabo et al. 2003) are mainly important for host defense against intracellular pathogens, including viruses, protozoa, and bacteria; they are also responsible for the development of certain forms of organ-specific autoimmunity. One of the major functions of Th1 cells is to activate macrophages through IFN- $\gamma$ production.

Th2 cells are critical for mediating immune responses against extracellular parasites, including helminthes. These cells are also responsible for the pathogenesis of inflammatory asthmatic and allergic diseases. By producing IL-4, Th2 cells induce B-cell immunoglobulin (Ig) switching to IgG1 and IgE (Kopf et al. 1993); by producing IL-5, Th2 cells recruit eosinophils (Coffman et al. 1989); and by producing IL-13, Th2 cells can induce the movement of smooth muscle cells and mucus production by epithelial cells (Urban et al. 1998; Kuperman et al. 2002; Wynn 2003). IL-4 and IL-13 produced by Th2 cells can also induce alternatively activated macrophages (Gordon 2003).

Th17 cells are essential for orchestrating immune responses to extracellular bacteria and fungi. They are also responsible for different forms of autoimmunity, including psoriasis, multiple sclerosis, rheumatoid arthritis, and inflammatory bowel diseases (Ouyang et al. 2008; Korn et al. 2009). Th17 cells are also involved in severe asthma (McKinley et al. 2008). Th17 cells produce three major cytokines: IL-17A, IL-17F, and IL-22. IL-17A and IL-17F have redundant functions in diseases, but they may also have unique functions (Iwakura et al. 2011). The major function of IL-17A and IL-17F is to recruit and activate neutrophils. They can also stimulate different cell types to produce inflammatory cytokines, including IL-6. IL-22 is a critical cytokine for stimulating cells at mucosal barriers to produce antimicrobial peptides and proinflammatory cytokines and chemokines (Liang et al. 2006).

Treg cells include thymus-derived Treg (tTreg) cells and peripherally derived Treg ( $\mathrm{p}$ Treg) cells (Shevach 2009; Sakaguchi et al. 2010; Josefowicz et al. 2012; Abbas et al. 2013). Together with the tTreg cells, pTreg cells play important roles in maintaining immune tolerance and regulating the magnitude of immune responses by controlling the differentiation and functions of $\mathrm{T}$ effector cells (Korn et al. 2009; Zhu et al. 2010; Crotty 2011; Bilate and Lafaille 2012).

\section{CYTOKINE-MEDIATED SIGNAL TRANSDUCERS AND ACTIVATORS OF TRANSCRIPTION (STATs) ACTIVATION IS CRITICAL FOR Th-CELL-FATE DETERMINATION}

Th-cell differentiation involves T-cell activation. Indeed, the strength of TCR signaling has a ma- 
jor impact on Th-cell-fate determination (Tao et al. 1997). Sometimes the TCR signaling strength may even have a dominant effect over adjuvants that usually create the cytokine environments that drive $\mathrm{T}$-cell differentiation (Tubo et al. 2013; Nelson et al. 2014; van Panhuys et al. 2014). In particular, stimulation with low-dose peptide favors Th2-cell differentiation (Yamane et al. 2005), consistent with the finding that resting dendritic cells (DCs) promote Th2-cell differentiation (Stumbles et al. 1998; Everts et al. 2009; Steinfelder et al. 2009). TCR costimulation mediated by $\mathrm{CD} 28$, which is required for optimal T-cell activation, is also involved in Th-cell differentiation (Seder et al. 1994). In contrast, cytotoxic T-lymphocyte-associated protein 4 (CTLA-4) negatively regulates T-cell differentiation (Oosterwegel et al. 1999; BourJordan et al. 2003).

It is well known that, besides TCR-mediated signaling, cytokine-mediated signals are critical for the differentiation of Th cells. For example, IL-12, mainly produced by antigen-presenting cells, including macrophages and DCs, induces Th1-cell differentiation (Hsieh et al. 1993). IL12 activates a transcription factor, STAT4, in differentiating CD4 T cells (Hsieh et al. 1993; Kaplan et al. 1996b; Thierfelder et al. 1996). IFN- $\gamma$, which is produced by Th1 cells themselves, also promotes Th1-cell differentiation through activating STAT1 (Lighvani et al. 2001; Afkarian et al. 2002; Martin-Fontecha et al. 2004). Indeed, either IL-12 or IFN- $\gamma$ is capable of inducing Th1-cell differentiation at least in vitro (Zhu et al. 2012). However, during Toxoplasma gondii infection, which elicits a robust Th1 response, IFN- $\gamma$ signaling seems to be dispensable for generating IFN- $\gamma$-producing T cells, whereas IL-12 is essential.

IL-4 induces Th2-cell differentiation by activating STAT6 (Kaplan et al. 1996a; Shimoda et al. 1996; Takeda et al. 1996). A constitutively active STAT6 mutant is sufficient to replace IL-4 in inducing Th2-cell differentiation (Kurata et al. 1999; Zhu et al. 2001). However, under certain circumstances, Th2-cell differentiation in vivo particularly in response to parasite infection may occur in an IL-4/IL-4R $\alpha /$ STAT6independent manner (Finkelman et al. 2000;
Jankovic et al. 2000; Min et al. 2004; Voehringer et al. 2004; van Panhuys et al. 2008).

In addition to IL-4, IL-2 through activating STAT5 is critical for the differentiation of Th2 cells in vitro (Zhu et al. 2003; Cote-Sierra et al. 2004). IL-2-mediated STAT5 activation is detectable $24 \mathrm{~h}$ after T-cell activation with a low dose of TCR stimulation, which induces Th2 differentiation (Yamane et al. 2005). CD4 T-cell proliferation and survival only need low levels of STAT5 activation (Moriggl et al. 1999; Cote-Sierra et al. 2004); however, Th2-cell differentiation requires high levels of STAT5 activation (Kagami et al. 2000, 2001; Zhu et al. 2003; Cote-Sierra et al. 2004). Other cytokines such as IL-7 and thymic stromal lymphopoietin (TSLP) can also activate STAT5 in T cells. Indeed, TSLP expression may trigger the initiation of Th2-cell differentiation in vivo (Ito et al. 2005; Zhou et al. 2005; Liu 2006; Sokol et al. 2008). Although TSLP mainly acts on DCs (Ito et al. 2005; Liu et al. 2007), it may also directly stimulate naïve CD4 T cells to become Th2 cells (Al-Shami et al. 2005; Omori and Ziegler 2007; Rochman et al. 2007; He et al. 2008). IL-7 can promote Th2-cell differentiation in vitro; however, its physiological function during Th2 differentiation in vivo is still elusive. Activated STAT5 directly regulates IL-4 production by binding to the Il4/Il13 locus at different regulatory regions (Zhu et al. 2003; Cote-Sierra et al. 2004; Liao et al. 2008). Furthermore, IL-2-mediated STAT5 activation induces IL-4R $\alpha$ expression at the early stage of Th2-cell differentiation (Liao et al. 2008).

For Th17 and pTreg differentiation, TGF- $\beta$ is involved (Chen et al. 2003; Korn et al. 2009). Together with IL-2-mediated STAT5 activation, TGF- $\beta$ induces Treg differentiation; on the other hand, together with IL-6-mediated STAT3 activation, TGF- $\beta$ induces Th17-cell differentiation (Bettelli et al. 2006; Veldhoen et al. 2006). IL-21 and IL-23 have a similar function as IL-6 in inducing STAT3 activation and, thus, Th17cell differentiation. However, IL-6, IL-21, and IL-23 may be involved in the different stages of Th17-cell development and maintenance (Korn et al. 2009). IL-2 signaling is important for Treg generation. In the absence of IL-2, IL-2R $\alpha$, or IL-2R $\beta$, Treg-cell numbers are reduced and mice 
J. Zhu

or humans bearing mutations in the genes encoding IL-2, IL-2R $\alpha$, or IL-2R $\beta$ develop autoimmune disease (Fontenot et al. 2005; Caudy et al. 2007). In contrast, IL-2-mediated STAT5 activation suppresses Th17-cell differentiation (Laurence et al. 2007; Liao et al. 2011; Yang et al. 2011).

\section{CYTOKINE-MEDIATED POSITIVE FEEDBACK DURING Th-CELL DIFFERENTIATION}

The cytokine-mediated positive feedback mechanism is one of the basic principles of Th-cell differentiation. During Th1-cell differentiation, IFN- $\gamma$ produced by developing Th1 cells may instruct IFN- $\gamma$ nonproducers to produce IFN$\gamma$. Similarly, IL-4 produced during Th2-cell differentiation may induce IL-4 expression by the previous IL-4 nonproducers. Furthermore, low amounts of IFN- $\gamma$ or IL- 4 derived from $\mathrm{T}$ cells may further induce these cells to produce high levels of IFN- $\gamma$ or IL- 4 in an autocrine manner. Therefore, Th1- and Th2-cell differentiation is enforced by the positive feedback loops. TGF- $\beta$ produced by Treg cells may be important for the generation of pTreg cells (Andersson et al. 2008). Th17 cells are also capable of producing either TGF- $\beta 1$ or TGF- $\beta 3$, both of which may serve as positive feedback mechanisms for Th17-cell differentiation (Gutcher et al. 2011; Lee et al. 2012). Because TGF- $\beta$ induces both Th17 and pTreg-cell differentiation and both cell types can produce TGF- $\beta$, how TGF- $\beta$ exactly works in vivo may depend on other factors such as the presence of inflammatory cytokines and the stage of Th-cell differentiation.

\section{MASTER TRANSCRIPTION FACTORS DICTATE T-CELL DIFFERENTIATION}

Although networks of transcription factors regulate Th-cell differentiation (Zhu and Paul 2010b; Ciofani et al. 2012; Hu et al. 2013; Yosef et al. 2013), lineage-specific master transcription factors play the most critical roles during the differentiation process (Fig.1). T-bet is the master transcription factor for Th1-cell differentiation, and it directly regulates IFN- $\gamma$ production (Szabo et al. 2000, 2002). Because IFN- $\gamma$ also induces T-bet expression, this explains the positive feedback for Th1-cell differentiation (Lighvani et al. 2001; Afkarian et al. 2002). IL-12 can also induce T-bet independent of IFN- $\gamma$ signaling (Yang et al. 2007; Zhu et al. 2012). Thus, IL-12 and IFN- $\gamma$ redundantly induce $\mathrm{T}$-bet expression both in vitro and in vivo. In addition to IL-12 and IFN- $\gamma$, other cytokines such as IL-27 and type I IFNs are also capable of inducing T-bet, although their actual functions during Th-cell differentiation in vivo are still elusive (Zhu et al. 2012). T-bet is capable of inducing its own expression (Mullen et al. 2001); however, such autoregulation may not be required when either IL-12 or IFN- $\gamma$ is present (Zhu et al. 2012). Nevertheless, T-bet collaborates with STAT4 to induce optimal IFN- $\gamma$ production, and one of the main functions of T-bet in Th1-cell differentiation is to remodel the Ifng locus. Genome-wide study has shown that $\mathrm{T}$-bet directly regulates a large number of Th1-specific genes (Zhu et al. 2012).

GATA3 is the master transcription factor for Th2-cell differentiation (Zhang et al. 1997; Zheng and Flavell 1997; Pai et al. 2004; Zhu et al. 2004). Retroviral expression of GATA3 is sufficient to induce endogenous GATA3 expression (Ouyang et al. 1998, 2000); however, GATA3 may not be required for its own expression when IL-4 is present (Wei et al. 2011). Unlike T-bet, which is not expressed in naïve T cells, GATA 3 is expressed in naïve $\mathrm{CD} 4^{+} \mathrm{T}$ cells at low levels, possibly because of its critical role during CD4 T-cell development in the thymus (Ho et al. 2009; Wei et al. 2011). STAT6 activation by IL-4 is one of the major inducers for GATA3 up-regulation. However, low-dose TCR stimulation is sufficient to up-regulate GATA3 expression independent of IL-4/STAT6 signaling (Yamane et al. 2005); this may offer a mechanism through which IL-4-independent Th2 differentiation may occur in vivo. Alternatively, the initiation of Th2-cell differentiation in vivo may occur with low amounts of GATA3 expression when STAT5 is highly activated (Zhu et al. 2003; Cote-Sierra et al. 2004; Rochman et al. 2009). Nevertheless, both IL-4-dependent and IL-4-independent Th2-cell differentiation re- 


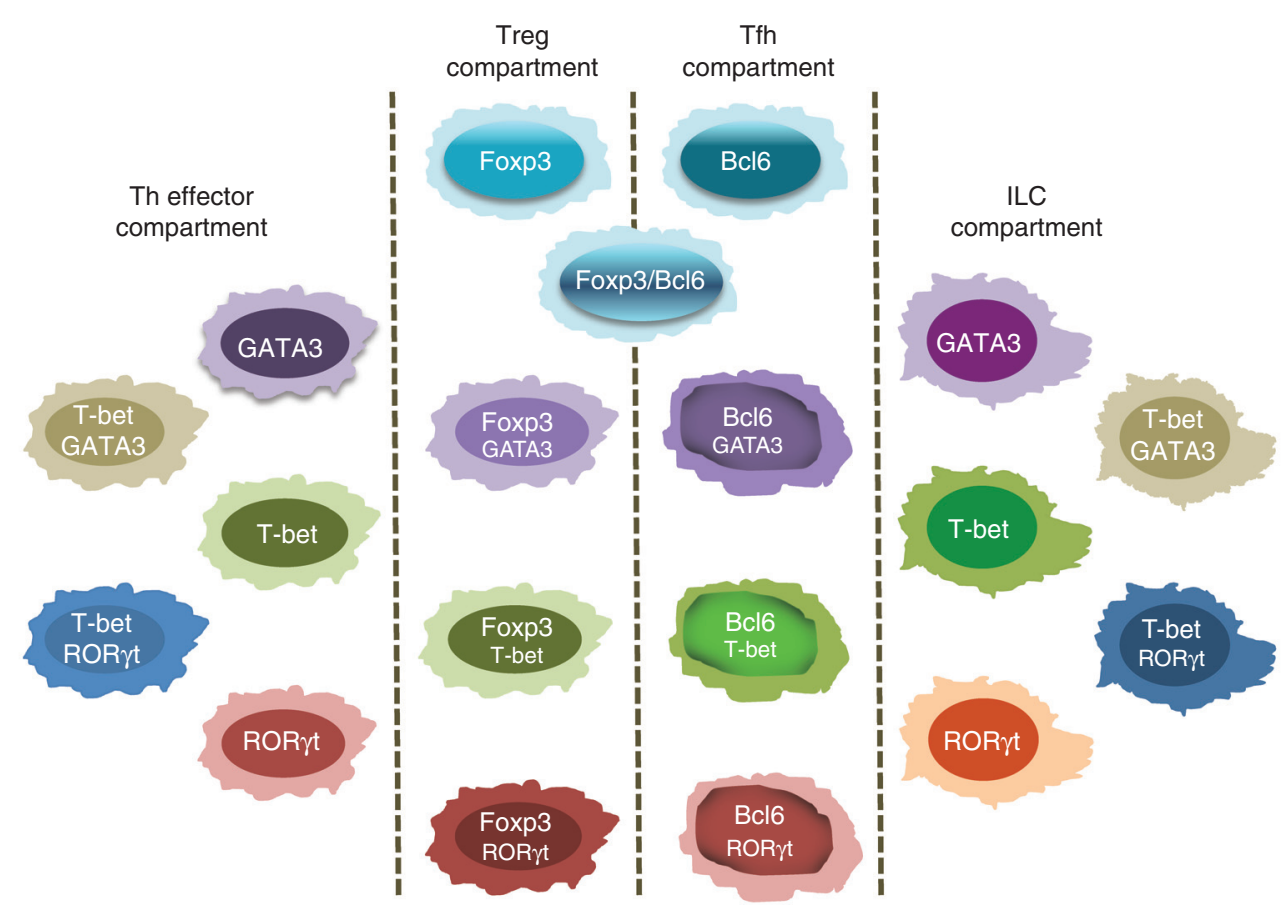

Figure 1. Combinatorial expression of master transcription factors determines the heterogeneity and functionality of effector T helper (Th) cells, follicular Th (Tfh) cells, regulatory $\mathrm{T}$ (Treg) cells, and innate lymphoid cell (ILC) subsets. T-bet, GATA3, and ROR $\gamma \mathrm{t}$ are the master transcription factors of distinct Th cell and ILC subsets. Within the Th effector compartment, T-bet/ROR $\gamma \mathrm{t}$ coexpressing cells have been found under inflammation conditions. These cells could be derived from either T-bet- or ROR $\gamma \mathrm{t}$-single positive cells. During type 2 immune responses, GATA3/T-bet coexpressing cells are also found. Similarly, in the ILC compartment, NKp46 ${ }^{+}$ILC3s coexpress T-bet and ROR $\gamma$ t. Bcl6 is the master regulator for Tfh cells. Subsets of Tfh cells may either express low levels of effector master regulators, T-bet, GATA3, or ROR $\gamma$ t, or have expressed one of these factors during their development. Interestingly, all of these master regulators, T-bet, GATA3, ROR $\gamma \mathrm{t}$, and Bcl6, can be expressed by subsets of Foxp3-expressing Treg cells albeit at lower levels. Furthermore, although it is not indicated in the figure, all of these lymphocytes can express GATA3 but at various levels.

quire GATA3 (Zhu et al. 2004). Interestingly, during Th1 and/or Th17 differentiation, GATA3 expression is down-regulated (Zheng and Flavell 1997; Wei et al. 2011).

GATA3 may promote Th2-cell differentiation via different mechanisms (Yagi et al. 2011). Genome-wide profiling of GATA3 binding indicates that it directly binds to the Il4/Il13 gene locus at various regions (Wei et al. 2011). Through its binding to the promoters of the Il5 and the $I l 13$ genes, GATA3 induces $I l 5$ and $I l 13$ transcription (Yamashita et al. 2002; Tanaka et al. 2011). However, GATA3 mainly affects Il4 expression through regulating epigenetic modifications at the Th2 cytokine gene locus.
Therefore, while GATA3 is required for the acquisition of IL-4-producing capacity by Th2 cells, in fully differentiated Th2 cells, GATA 3 is no longer important for IL-4 production but it remains essential for the transcription of the Il5 and Ill3 (Zhu et al. 2004). In addition, GATA3 directly regulates many other Th2specific genes including Il1rl1, which encodes T1/ST2, the IL-33 receptor (Wei et al. 2011).

ROR $\gamma \mathrm{t}$ is the master transcription factor for Th17-cell differentiation (Ivanov et al. 2006). RORyt loss-of-function mutations in human patients results in susceptibility to both Candida and Mycobacterium infections (Okada et al. 2015). The induction of ROR $\gamma \mathrm{t}$ expression de- 
J. Zhu

pends on STAT3 activation by IL-6, IL-21, and/ or IL-23 (Zhu and Paul 2008; Korn et al. 2009). ROR $\gamma$ t directly regulates IL-17A and IL-17F expression. At the genome scale, ROR $\gamma \mathrm{t}$ binds to and regulates only a selected set of Th17specific genes after BATF/IRF4 and STAT3 have initiated the Th17 differentiation program (Ciofani et al. 2012).

The master regulator for Treg generation and function is Foxp3 (Fontenot et al. 2003; Hori et al. 2003). Mutations in the human FOXP3 gene are responsible for the immunodysregulation polyendocrinopathy enteropathy $\mathrm{X}$-linked (IPEX) syndrome, and mutations in the Foxp3 gene in mice, such as Scurfy mice, result in fatal autoimmune diseases. Genomewide analysis indicates that Foxp3 directly binds to hundreds of genes, many of which are either positively or negatively regulated by Foxp3, especially in the thymus (Zheng et al. 2007). Some of Foxp3-regulated genes encode molecules that regulate gene expression and/or are involved in epigenetic modifications.

\section{CROSS-REGULATION OF Th-CELL DIFFERENTIATION}

During Th-cell differentiation toward a specific type, signals/pathways that induce such differentiation also repress the alternative lineage fates. At the transcriptional level, the transcription factors that are either activated or induced in one lineage often cross-regulate the expression and/or functions of the transcription factors that are involved in making other lineage decisions. For example, overexpression of T-bet suppresses Gata3 transcription (Usui et al. 2006) and inhibits GATA3 function through direct protein-protein interaction (Hwang et al. 2005). Interestingly, T-bet and GATA3 binding sites colocalize at several critical Th1- or Th2specific genes (Jenner et al. 2009; Kanhere et al. 2012; Zhu et al. 2012). It has also been shown that endogenous T-bet inhibits GATA3 function during Th1-cell differentiation, thus preventing the activation of a "default" program for Th2-cell differentiation (Zhu et al. 2012). On the other hand, during Th2-cell differentiation, GATA3 may suppress Th1-cell differenti- ation by repressing STAT4 expression (Usui et al. 2003), and suppressing Runx3-mediation IFN- $\gamma$ production (Yagi et al. 2010) as well as silencing the Tbx21 locus (Wei et al. 2011). Cross-regulation has also been found between T-bet and ROR $\gamma$ t (Lazarevic et al. 2011) and between Foxp3 and ROR $\gamma$ t (Yang et al. 2008; Zhou et al. 2008). ROR $\gamma$ t and Foxp3 may antagonize each other through protein-protein interaction (Yang et al. 2008; Zhang et al. 2008; Zhou et al. 2008).

\section{NONCANONICAL Th SUBSETS THAT COEXPRESS MULTIPLE MASTER REGULATORS}

Master regulators are usually expressed in a celltype-specific manner (i.e., T-bet for Th1, GATA3 for Th2, ROR $\gamma$ t for Th17, and Foxp3 for Treg cells) (Fig. 1). However, because both Th17- and Treg-cell differentiation require TGF- $\beta$, ROR $\gamma$ t and Foxp 3 are often coexpressed, presumably at early stages of Th17/Treg-cell differentiation. These cells may represent an intermediate stage before they eventually commit to either Th17 or Treg cells (Yang et al. 2008; Zhou et al. 2008; Komatsu et al. 2014). Interestingly, ROR $\gamma \mathrm{t} /$ Foxp3-coexpressing Treg cells, possibly representing a specialized Treg subset, are abundant in the large intestine (Ohnmacht et al. 2015; Sefik et al. 2015). Indeed, Tregspecific deletion of ROR $\gamma$ t results in gut inflammation with an uncontrolled Th2 response (Ohnmacht et al. 2015).

In addition to ROR $\gamma \mathrm{t}$, T-bet and GATA 3 can be expressed by Treg subsets as well. Therefore, it has been suggested that Treg cells may hijack the master regulators of distinct $\mathrm{T}$ effector cells to specifically control a given type of immune response. According to this model, T-bet expression by Treg cells is critical for inhibiting Th1 responses (Koch et al. 2009). However, Treg-specific deletion of T-bet does not result in the development of Th1-related autoimmune diseases, indicating that $\mathrm{T}$-bet is not required for Treg cells to control autoreactive Th1 cells at steady state (Yu et al. 2015). Because the functions of Treg cells during inflammation and/or immune responses may be different from their 
functions at steady state, it remains to be determined whether T-bet expression in Treg cells is important for their ability to limit Th1-related immune responses (Oldenhove et al. 2009; Yamaguchi et al. 2011).

GATA3 is expressed in all T cells, albeit at different levels. Interestingly, some Treg cells can express high levels of GATA3 (Wang et al. 2011; Wohlfert et al. 2011; Rudra et al. 2012; Yu et al. 2015), potentially explaining why a slight reduction in Foxp3 expression results in a Th2 phenotype in these "Treg cells" (Wan and Flavell 2007). In fact, even with normal levels of Foxp3 expression, GATA3 may induce the expression of many "Th2-specific" genes such as Illrl1 and Ccr8 in Treg cells (Wei et al. 2011). One study has shown that GATA3 deletion in Treg cells results in spontaneous Th2-like autoimmunity (Wang et al. 2011), but other studies show that the mice with GATA3 deletion specifically in Treg cells do not develop Th2-specific systemic diseases (Wohlfert et al. 2011; Rudra et al. 2012; Yu et al. 2015).

Interestingly, T-bet- and GATA3-expressing Treg cells do not represent stable Treg subsets. The expression T-bet and GATA3 in Treg cells is dynamic ( $\mathrm{Yu}$ et al. 2015). Although deletion of either T-bet or GATA3 in Treg cells does not affect the overall function of these cells, Treg cells lacking expression of both T-bet and GATA3 up-regulate ROR $\gamma \mathrm{t}$ expression and acquire IL-17-producing capacity. These Treg cells are unstable and many lose Foxp3 expression over time. Thus, dynamic expression of T-bet and GATA3 together with cross-regulation among T-bet, GATA3, ROR $\gamma$ t, and Foxp3 are important for maintaining Treg functions (Yu et al. 2015).

In addition to the heterogeneity of Tregs, within $\mathrm{T}$ effector populations, multiple master regulators may also be expressed in the same cell. For example, T-bet/ROR $\gamma \mathrm{t}$ coexpressing cells are found in the gut and inflamed brain (Ivanov et al. 2006; Hirota et al. 2011). Many of these cells are capable of expressing both IFN- $\gamma$ and IL-17 (Lee et al. 2009; Ghoreschi et al. 2010; Lexberg et al. 2010; Hirota et al. 2011). T-bet/ROR $\gamma \mathrm{t}$ (IFN- $\gamma / \mathrm{IL}-17$ ) coexpressing $\mathrm{T}$ cells, which are specific for Candida albi- cans antigens, are also found in human patients (Zielinski et al. 2012). Interestingly, these cells may represent an important population that is involved in immune responses to Mycobacterium tuberculosis $(M t b)$ infection in humans. ROR $\gamma$ t-deficient patients fail to control $M t b$ infections (Okada et al. 2015). Besides T-bet/ROR $\gamma t$ coexpressing cells, GATA3/T-bet coexpressing cells have been detected in helminth-infected animals (Peine et al. 2013) and GATA3/RORyt coexpressing cells are found in asthmatic mice and patients (Cosmi et al. 2010; Wang et al. 2010).

\section{EPIGENETIC MODIFICATIONS AND CELL PLASTICITY}

Different modifications at the histones binding to the genomic regions correlate with gene activation or silencing (Barski et al. 2007). Trimethylation at the lysine position 4 of histone 3 (H3K4me3), particularly in gene-promoter regions, is usually associated with active gene loci. On the other hand, H3K27me3 is generally a marker of repressed genes. Epigenetic status at the effector cytokine loci is usually reflected by $\mathrm{H} 3 \mathrm{~K} 4 \mathrm{me} 3$ in cells that express such cytokines, or by $\mathrm{H} 3 \mathrm{~K} 27 \mathrm{me} 3$ in cells where these cytokine genes are silenced (Wei et al. 2009). However, bivalent modifications with both $\mathrm{H} 3 \mathrm{~K} 4 \mathrm{me} 3$ and $\mathrm{H} 3 \mathrm{~K} 27 \mathrm{me}$, which are indicative for the genes poised for expression, are found in the promoters of the master regulator genes, such as Tbx21, Gata3, and Rorc, etc., even in the cells that do not express such transcription factors (Wei et al. 2009). Such bivalent modifications may allow the induction of a master regulator expression in cells of alternative lineage fate, resulting in the generation of master regulator coexpressing cells and cell plasticity. Therefore, a transient signal that alters the balance of key master regulators, which will cross-regulate each other when coexpressed, may ultimately result in a lineage switch.

Although there are some reports showing that Th1 and Th2 cells may alter their lineage fates (Hegazy et al. 2010), these cells are relatively stable (Zhu and Paul 2010a). Cell plasticity is more common for Th17 and Treg cells (Zhou et al. 2009a). Th17 cells may acquire IFN- $\gamma$ - 
J. Zhu

producing capacity in a T-bet-dependent manner (Mathur et al. 2006; Bending et al. 2009; Lee et al. 2009). Through a fate-mapping study, it has been shown that IFN- $\gamma$-producing cells found in the brain of autoimmune mice are largely derived from the cells that express IL17 (Hirota et al. 2011). Th17 cells may also trans-differentiate into Treg cells when inflammation is resolved (Gagliani et al. 2015). Although several studies have shown that Treg cells are stable even under inflamed conditions (Rubtsov et al. 2010; Sakaguchi et al. 2013), other studies have shown the possible switch from Treg cells to Th1, Th2, or Th17 cells (Xu et al. 2007; Komatsu et al. 2009, 2014; Oldenhove et al. 2009; Zhou et al. 2009b; Noval Rivas et al. 2015).

\section{RELATIONSHIP BETWEEN T EFFECTOR CELLS AND CYTOKINE-PRODUCING Tfh CELLS}

A critical function of CD4 T cells during immune responses is to help $B$ cells produce antibodies and Ig class switching (Fig. 1). It has been shown that CD4 Th cells that are found in the B-cell follicle, termed as Tfh cells, are critical for exerting such functions (Crotty 2011). Th-cell effects on $\mathrm{B}$ cells rely on cytokine production; although IL-4 is important for the Ig class switching to IgE and IgG1 (Kopf et al. 1993; King and Mohrs 2009; Reinhardt et al. 2009; Zaretsky et al. 2009), IFN- $\gamma$ induces Ig switching to IgG2a/IgG2c. Even though IL-21 produced by Tfh cells is important for helping B cells, there are at least two different types of Tfh cells, with one type producing IFN- $\gamma$ and the other IL-4. In fact, most of the IL-4-producing Th cells in vivo have a Tfh phenotype (King and Mohrs 2009). Different from conventional Th2 cells, however, IL-4-producing Tfh cells do not express IL-13 (Liang et al. 2012).

Tfh cells are considered as a fifth major Thcell population that is different from conventional Th1, Th2, Th17, and Treg cells (Nurieva et al. 2008). Tfh-cell differentiation requires STAT3 activation, presumably by IL-21, but IL-2-mediated STAT5 activation suppresses Tfh-cell generation (Nurieva et al. 2008, 2012;
Johnston et al. 2012). The master transcription factor for Tfh cells is Bcl6 (Johnston et al. 2009; Nurieva et al. 2009). Interestingly, some Treg cells are also found in the B-cell follicle and these cells coexpress Foxp3 and Bcl6. These cells are named follicular regulatory $\mathrm{T}$ (Tfr) cells (Chung et al. 2011; Linterman et al. 2011). Tfr cells may play an important role in limiting the functions of Tfh cells in activating B cells.

Tfh cells do not express or express very low levels of T-bet and GATA3. However, IgE class switching completely depends on GATA3 expression, indicating that GATA3 is required for the development of IL-4-producing Tfh cells (Zhu et al. 2004). It is possible that low levels of GATA3 expression in Tfh cells are sufficient for these cells to produce IL-4 production (Yusuf et al. 2010; Liang et al. 2012). Alternatively, just like the dynamic expression of GATA3 found in Treg cells, as mentioned earlier ( $\mathrm{Yu}$ et al. 2015), GATA3 may have been expressed at high levels at early stage of IL-4-producing Tfh-cell differentiation. Once the Il4 locus is remodeled by GATA3, Tfh cells no longer require GATA3 for IL-4 production and thus do not need to express GATA3. This is consistent with the observation that in fully differentiated Th2 cells, Gata3 deletion does not abolish IL-4 production (Zhu et al. 2004). Similarly, transient expression of $\mathrm{T}$-bet during the early stage of Tfh-cell differentiation may allow these cells to acquire IFN- $\boldsymbol{\gamma}$-producing capacity.

The developmental relationship between IFN- $\gamma$ - or IL-4-producing Tfh cells and conventional Th1 or Th2 cells is still elusive. In vitro experiments suggest that conventional Th1 or Th2 cells can become IFN- $\boldsymbol{\gamma}$ - or IL-4-producing Tfh cells or differentiated Tfh cells can acquire IFN- $\gamma$ - or IL-4-producing capacity ( $\mathrm{Lu}$ et al. 2011). In vivo, activated IL-4-producing $T$ cells may subsequently acquire a Tfh-cell phenotype through their interaction with B cells (Zaretsky et al. 2009). It is also possible that activated $T$ cells may acquire IFN- $\gamma$ - or IL-4-producing capacity and a Tfh phenotype simultaneously, and thus their fate to become either conventional Th1/Th2 effector cells or specific cytokineproducing Tfh cells may have been determined at very early stages of $\mathrm{T}$-cell differentiation $(\mathrm{Na}$ - 
kayamada et al. 2011; Johnston et al. 2012; Oestreich et al. 2012). It is interesting to point out that Tfh cells may be an important source for generating memory Th cells, which could subsequently give rise to conventional Th effector cells on reactivation (Luthje et al. 2012). In the future, genome-wide assessment of the transcriptomes and epigenomes of conventional Th cells, cytokine-producing Tfh-cell subsets and Th memory cells is necessary to further understand the relationship between these closely related cell types.

\section{RELATIONSHIP BETWEEN Th CELLS AND INNATE LYMPHOID CELLS}

During the past few years, ILCs have drawn much attention in the immunology field (Artis and Spits 2015). ILCs do not express antigen receptors, but they can respond to many inflammatory cytokines, such as IL-1, IL-12, IL-18, IL-23, IL-25, and IL-33, to produce their own cytokines, including IFN- $\gamma$, IL-5/13, and IL-17/ 22 . ILCs express IL-7R $\alpha$ and at least partially depend on IL-7 and/or TSLP for their development. Because of their distinct cytokine-producing capacity, ILCs are classified into group 1 ILCs (ILC1s) that produce IFN- $\gamma$, group 2 ILCs (ILC2s) that produce IL-5 and IL-13, and group 3 ILCs (ILC3s) that produce IL-17 and IL22. Not only do ILC subsets produce similar cytokines to those produced by Th-cell subsets, but ILCs also use the same set of master regulators, namely, T-bet, GATA3, and ROR $\gamma$ t for their development and function. For example, the Th2 master regulator, GATA3, is also critical for ILC2 development and the functional maintenance of these cells (Hoyler et al. 2012; Mjosberg et al. 2012; Furusawa et al. 2013; Klein Wolterink et al. 2013; Yang et al. 2013; Yagi et al. 2014). Although some researchers have classified natural killer (NK) cells into ILC1s based on their cytokine production, NK cells are in fact the innate counterparts of CD8 T cells in the adaptive system (Cortez and Colonna 2016; Spits et al. 2016). Both NK and CD8 T cells express transcription factor Eomes. Developmentally, all non-NK ILCs (or Th-like ILCs, or IL-7R $\alpha$-expressing ILCs) depend on GATA3, whereas NK cells do not (Yagi et al. 2014); this mirrors the critical function of GATA3 in specifying CD4 but not CD8 lineage fate during T-cell development (Ho et al. 2009). In addition, GATA3 regulates IL-7R $\alpha$ expression in both T cells and ILCs (Wang et al. 2013; Zhong et al. 2016).

Because of similarities between ILC and Th subsets (Yagi et al. 2014; Koues et al. 2016; Shih et al. 2016), a specific type of ILCs may participate in the same class of immune responses in a similar manner to corresponding distinct Th subsets. Therefore, ILC2s are important players during type 2 immune responses, including immunity against helminth infections (Fallon et al. 2006; Moro et al. 2010; Neill et al. 2010; Price et al. 2010) and during allergic lung and skin inflammation (Chang et al. 2011; Monticelli et al. 2011; Halim et al. 2012; Roediger et al. 2013; Kim et al. 2014). Similarly, ILC1s may participate in type 1 immune responses and ILC3s are important for controlling extracellular bacteria, which induce Th17 responses (Qiu et al. 2013; Klose et al. 2014; Sano et al. 2015). As mentioned above, ILCs mainly respond to cytokine stimulation. Interestingly, in fully differentiated Th cells, IL-1 family receptors IL-18R, IL-33R, and IL-1R, which are preferentially expressed by ILC1s, ILC2s, and ILC3s, respectively, are also selectively expressed by Th1, Th2, and Th17 cells, respectively (Guo et al. 2009, 2012). As a result, just like ILCs, Th cells can also respond to cytokine stimulation, which is independent of TCR stimulation, to produce effector cytokines in vivo (Guo et al. 2015).

One major difference between ILCs and Th cells is antigen specificity. Because ILCs do not recognize specific antigen and they are already developed even before possible microbial threats, these cells provide the first line of host defense to infections. Their unique position in tissue sites fits quite well with their functionality. Interestingly, the same type of ILCs and Th cells may cross talk to each other. For example, IL-13 produced by ILC2s on activation can induce the migration of DCs to the draining lymph nodes, and these migratory DCs preferentially induce Th2-cell differentiation (Halim et al. 2014). In addition, some ILC2s, by expressing major 
J. Zhu

histocompatibility complex (MHC) class II, can activate $\mathrm{T}$ cells, and IL-2 produced by $\mathrm{T}$ cells may then act back onto ILC2s to influence their activation and cytokine production (Mirchandani et al. 2014; Oliphant et al. 2014). Cross talk between ILC3s and Th17 cells has also been reported (Sano et al. 2015). Nevertheless, the functions of ILCs and Th cells may be substantially redundant. Optimal activation of ILCs is sufficient to control infections in the absence of Th cells, as shown in several mouse models. Interestingly, however, humans without ILCs, which can result because of the failure of ILC reconstitution after bone marrow transplantation, are capable of controlling infections (Vely et al. 2016). However, the collaboration as well as labor division between ILCs and Th cells may allow the host to survive severe infections. Because of the activation of either ILCs or Th cells alone is sufficient to induce many inflammatory diseases, investigating the development and functions of both ILCs and Th subsets is clinically relevant.

\section{CONCLUDING REMARKS}

CD4 Th cells are professional cytokine-producing cells. To acquire a unique cytokine-producing profile, naïve CD4 T cells need to go through a differentiation process. During Th-cell differentiation, TCR and cytokine-mediated signaling pathways induce activation of STAT proteins followed by up-regulation of lineage-specific master transcription factors. Activated STAT proteins collaborate with lineage-specific master regulators such as T-bet, GATA3, and ROR $\gamma \mathrm{t}$ in epigenetically remodeling the respective cytokine loci and regulating cytokine gene expression. Although these master regulators are usually expressed in a cell-type-specific manner, they can often be coexpressed. Furthermore, effector cell-related transcription factors can be expressed by Foxp3-expressing Treg cells, resulting in massively heterogeneous Th effector and regulatory populations. Bivalent histone modifications at the gene loci of master regulators may explain the coexpression of multiple factors, and the coexpression, dynamic induction, and cross-regulation of these master regu- lators may determine the plasticity of Th cells. Some master regulator coexpressers are relatively stable, that is, T-bet/ROR $\gamma \mathrm{t}$ coexpressers. Importantly, these cells are found abundant in several inflammatory settings; they are considered as the most potent cells in inducing autoimmunity and they may be an important cell population to fight against $M t b$ infection in humans. How T-bet and ROR $\gamma \mathrm{t}$, two mutually inhibitory transcription factors, may stably coexist in the same cell and what unique programs have been activated in these cells remain important questions. Investigation of Th- and ILC-cell heterogeneity and plasticity holds promise for finding specific treatments for a variety of human immunological diseases in the future. High-dimensional single-cell analyses, including single-cell RNAseq and CyTOF mass cytometry, may allow us to gain deeper insights into the immune responses mediated by $\mathrm{Th}$ cell and ILC subsets in autoimmunity, allergy, and infectious diseases.

\section{ACKNOWLEDGMENTS}

J.Z. is supported by the Division of Intramural Research (DIR), the National Institute of Allergy and Infectious Diseases (NIAID), and the National Institutes of Health (NIH).

\section{REFERENCES}

Abbas AK, Benoist C, Bluestone JA, Campbell DJ, Ghosh S, Hori S, Jiang S, Kuchroo VK, Mathis D, Roncarolo MG, et al. 2013. Regulatory T cells: Recommendations to simplify the nomenclature. Nat Immunol 14: 307-308.

Acosta-Rodriguez EV, Rivino L, Geginat J, Jarrossay D, Gattorno M, Lanzavecchia A, Sallusto F, Napolitani G. 2007. Surface phenotype and antigenic specificity of human interleukin 17-producing $\mathrm{T}$ helper memory cells. Nat Immunol 8: 639-646.

Afkarian M, Sedy JR, Yang J, Jacobson NG, Cereb N, Yang SY, Murphy TL, Murphy KM. 2002. T-bet is a STAT1induced regulator of IL-12R expression in naive $\mathrm{CD}^{+} \mathrm{T}$ cells. Nat Immunol 3: 549-557.

Al-Shami A, Spolski R, Kelly J, Keane-Myers A, Leonard WJ. 2005. A role for TSLP in the development of inflammation in an asthma model. J Exp Med 202: 829-839.

Andersson J, Tran DQ, Pesu M, Davidson TS, Ramsey H, O'Shea JJ, Shevach EM. 2008. CD ${ }^{+}$FoxP $^{+}$regulatory T cells confer infectious tolerance in a TGF- $\beta$-dependent manner. J Exp Med 205: 1975-1981. 
Artis D, Spits H. 2015. The biology of innate lymphoid cells. Nature 517: 293-301.

Barski A, Cuddapah S, Cui K, Roh TY, Schones DE, Wang Z, Wei G, Chepelev I, Zhao K. 2007. High-resolution profiling of histone methylations in the human genome. Cell 129: $823-837$.

Bending D, De la Pena H, Veldhoen M, Phillips JM, Uyttenhove C, Stockinger B, Cooke A. 2009. Highly purified Th17 cells from BDC2.5NOD mice convert into Th1-like cells in NOD/SCID recipient mice. JClin Invest 119: 565572.

Bettelli E, Carrier YJ, Gao WD, Korn T, Strom TB, Oukka M, Weiner HL, Kuchroo VK. 2006. Reciprocal developmental pathways for the generation of pathogenic effector $\mathrm{T}_{\mathrm{H}} 17$ and regulatory T cells. Nature 441: 235-238.

Bilate AM, Lafaille JJ. 2012. Induced $\mathrm{CD} 4{ }^{+} \mathrm{Foxp}^{+}$regulatory T cells in immune tolerance. Annu Rev Immunol 30: 733 758.

Bour-Jordan H, Grogan JL, Tang Q, Auger JA, Locksley RM, Bluestone JA. 2003. CTLA-4 regulates the requirement for cytokine-induced signals in $\mathrm{T}_{\mathrm{H}} 2$ lineage commitment. Nat Immunol 4: 182-188.

Caudy AA, Reddy ST, Chatila T, Atkinson JP, Verbsky JW 2007. CD25 deficiency causes an immune dysregulation, polyendocrinopathy, enteropathy, X-linked-like syndrome, and defective IL-10 expression from CD4 lymphocytes. J Allergy Clin Immunol 119: 482-487.

Chang YJ, Kim HY, Albacker LA, Baumgarth N, McKenzie AN, Smith DE, Dekruyff RH, Umetsu DT. 2011. Innate lymphoid cells mediate influenza-induced airway hyperreactivity independently of adaptive immunity. Nat Immunol 12: 631-638.

Chen W, Jin W, Hardegen N, Lei KJ, Li L, Marinos N, McGrady G, Wahl SM. 2003. Conversion of peripheral $\mathrm{CD} 4^{+} \mathrm{CD} 25^{-}$naive $\mathrm{T}$ cells to $\mathrm{CD} 4^{+} \mathrm{CD} 25^{+}$regulatory $\mathrm{T}$ cells by TGF- $\beta$ induction of transcription factor Foxp3. J Exp Med 198: 1875-1886.

Chung Y, Tanaka S, Chu F, Nurieva RI, Martinez GJ, Rawal S, Wang YH, Lim H, Reynolds JM, Zhou XH, et al. 2011. Follicular regulatory T cells expressing Foxp3 and Bcl-6 suppress germinal center reactions. Nat Med 17: 983-988.

Ciofani M, Madar A, Galan C, Sellars M, Mace K, Pauli F, Agarwal A, Huang W, Parkurst CN, Muratet M, et al. 2012. A validated regulatory network for Th17 cell specification. Cell 151: 289-303.

Coffman RL, Seymour BW, Hudak S, Jackson J, Rennick D. 1989. Antibody to interleukin-5 inhibits helminthinduced eosinophilia in mice. Science 245: 308-310.

Cortez VS, Colonna M. 2016. Diversity and function of group 1 innate lymphoid cells. Immunol Lett 179: 19-24.

Cosmi L, Maggi L, Santarlasci V, Capone M, Cardilicchia E, Frosali F, Querci V, Angeli R, Matucci A, Fambrini M, et al. 2010. Identification of a novel subset of human circulating memory $\mathrm{CD} 4^{+} \mathrm{T}$ cells that produce both IL-17A and IL-4. J Allergy Clin Immunol 125: 222-230.e1-4.

Cote-Sierra J, Foucras G, Guo L, Chiodetti L, Young HA, HuLi J, Zhu J, Paul WE. 2004. Interleukin 2 plays a central role in Th2 differentiation. Proc Natl Acad Sci 101:38803885.

Crotty S. 2011. Follicular helper CD4 T cells $\left(\mathrm{T}_{\mathrm{FH}}\right)$. Annu Rev Immunol 29: 621-663.
Everts B, Perona-Wright G, Smits HH, Hokke CH, van der Ham AJ, Fitzsimmons CM, Doenhoff MJ, van der Bosch J, Mohrs K, Haas H, et al. 2009. Omega-1, a glycoprotein secreted by Schistosoma mansoni eggs, drives Th2 responses. J Exp Med 206: 1673-1680.

Fallon PG, Ballantyne SJ, Mangan NE, Barlow JL, Dasvarma A, Hewett DR, McIlgorm A, Jolin HE, McKenzie AN. 2006. Identification of an interleukin (IL)-25-dependent cell population that provides IL-4, IL-5, and IL-13 at the onset of helminth expulsion. J Exp Med 203: 1105-1116.

Finkelman FD, Morris SC, Orekhova T, Mori M, Donaldson D, Reiner SL, Reilly NL, Schopf L, Urban JF Jr. 2000. Stat6 regulation of in vivo IL-4 responses. J Immunol 164: 2303-2310.

Fontenot JD, Gavin MA, Rudensky AY. 2003. Foxp3 programs the development and function of $\mathrm{CD} 4^{+} \mathrm{CD} 25^{+}$regulatory T cells. Nat Immunol 4: 330-336.

Fontenot JD, Rasmussen JP, Gavin MA, Rudensky AY. 2005. A function for interleukin 2 in Foxp3-expressing regulatory T cells. Nat Immunol 6: 1142-1151.

Furusawa J, Moro K, Motomura Y, Okamoto K, Zhu J, Takayanagi H, Kubo M, Koyasu S. 2013. Critical role of p38 and GATA3 in natural helper cell function. J Immunol 191: 1818-1826.

Gagliani N, Amezcua Vesely MC, Iseppon A, Brockmann L, Xu H, Palm NW, de Zoete MR, Licona-Limon P, Paiva RS Ching T, et al. 2015. Th17 cells transdifferentiate into regulatory $\mathrm{T}$ cells during resolution of inflammation. Nature 523: 221-225.

Ghoreschi K, Laurence A, Yang XP, Tato CM, McGeachy MJ, Konkel JE, Ramos HL, Wei L, Davidson TS, Bouladoux N, et al. 2010. Generation of pathogenic $\mathrm{T}_{\mathrm{H}} 17$ cells in the absence of TGF- $\beta$ signalling. Nature 467: 967-971.

Gordon S. 2003. Alternative activation of macrophages. Nat Rev 3: 23-35.

Guo L, Wei G, Zhu J, Liao W, Leonard WJ, Zhao K, Paul W. 2009. IL-1 family members and STAT activators induce cytokine production by Th2, Th17, and Th1 cells. Proc Natl Acad Sci 106: 13463-13468.

Guo L, Junttila IS, Paul WE. 2012. Cytokine-induced cytokine production by conventional and innate lymphoid cells. Trends Immunol 33: 598-606.

Guo L, Huang Y, Chen X, Hu-Li J, Urban JF Jr, Paul WE. 2015. Innate immunological function of $\mathrm{T}_{\mathrm{H}} 2$ cells in vivo. Nat Immunol 16: 1051-1059.

Gutcher I, Donkor MK, Ma Q, Rudensky AY, Flavell RA, Li MO. 2011. Autocrine transforming growth factor- $\beta 1$ promotes in vivo Th17 cell differentiation. Immunity 34: 396-408.

Halim TY, Krauss RH, Sun AC, Takei F. 2012. Lung natural helper cells are a critical source of Th2 cell-type cytokines in protease allergen-induced airway inflammation. Immunity 36: 451-463.

Halim TY, Steer CA, Matha L, Gold MJ, Martinez-Gonzalez I, McNagny KM, McKenzie AN, Takei F. 2014. Group 2 innate lymphoid cells are critical for the initiation of adaptive $T$ helper 2 cell-mediated allergic lung inflammation. Immunity 40: 425-435.

He R, Oyoshi MK, Garibyan L, Kumar L, Ziegler SF, Geha RS. 2008. TSLP acts on infiltrating effector T cells to drive 
allergic skin inflammation. Proc Natl Acad Sci 105: 11875-11880.

Hegazy AN, Peine M, Helmstetter C, Panse I, Frohlich A, Bergthaler A, Flatz L, Pinschewer DD, Radbruch A, Lohning M. 2010. Interferons direct Th2 cell reprogramming to generate a stable GATA- $3^{+}$T-bet ${ }^{+}$cell subset with combined Th 2 and Th 1 cell functions. Immunity 32: 116-128.

Hirota K, Duarte JH, Veldhoen M, Hornsby E, Li Y, Cua DJ, Ahlfors H, Wilhelm C, Tolaini M, Menzel U, et al. 2011. Fate mapping of IL-17-producing T cells in inflammatory responses. Nat Immunol 12: 255-263.

Ho IC, Tai TS, Pai SY. 2009. GATA3 and the T-cell lineage: Essential functions before and after T-helper-2-cell differentiation. Nat Rev 9: 125-135.

Hori S, Nomura T, Sakaguchi S. 2003. Control of regulatory $\mathrm{T}$ cell development by the transcription factor Foxp 3 . Science 299: 1057-1061.

Hoyler T, Klose CS, Souabni A, Turqueti-Neves A, Pfeifer D, Rawlins EL, Voehringer D, Busslinger M, Diefenbach A. 2012. The transcription factor GATA-3 controls cell fate and maintenance of type 2 innate lymphoid cells. Immunity 37: 634-648.

Hsieh CS, Macatonia SE, Tripp CS, Wolf SF, O'Garra A, Murphy KM. 1993. Development of $\mathrm{T}_{\mathrm{H}} 1 \mathrm{CD}^{+} \mathrm{T}$ cells through IL-12 produced by Listeria-induced macrophages. Science 260: 547-549.

Hu G, Tang Q, Sharma S, Yu F, Escobar TM, Muljo SA, Zhu J, Zhao K. 2013. Expression and regulation of intergenic long noncoding RNAs during $\mathrm{T}$ cell development and differentiation. Nat Immunol 14: 1190-1198.

Hwang ES, Szabo SJ, Schwartzberg PL, Glimcher LH. 2005. T helper cell fate specified by kinase-mediated interaction of T-bet with GATA-3. Science 307: 430-433.

Ito T, Wang YH, Duramad O, Hori T, Delespesse GJ, Watanabe N, Qin FX, Yao Z, Cao W, Liu YJ. 2005. TSLPactivated dendritic cells induce an inflammatory $\mathrm{T}$ helper type 2 cell response through OX40 ligand. J Exp Med 202: 1213-1223.

Ivanov II, McKenzie BS, Zhou L, Tadokoro CE, Lepelley A, Lafaille JJ, Cua DJ, Littman DR. 2006. The orphan nuclear receptor ROR $\gamma \mathrm{t}$ directs the differentiation program of proinflammatory IL-17 ${ }^{+} \mathrm{T}$ helper cells. Cell 126: $1121-$ 1133.

Iwakura Y, Ishigame H, Saijo S, Nakae S. 2011. Functional specialization of interleukin-17 family members. Immunity 34: 149-162.

Jankovic D, Kullberg MC, Noben-Trauth N, Caspar P, Paul WE, Sher A. 2000. Single cell analysis reveals that IL-4 receptor/Stat6 signaling is not required for the in vivo or in vitro development of $\mathrm{CD}^{+}$lymphocytes with a Th2 cytokine profile. J Immunol 164: 3047-3055.

Jenner RG, Townsend MJ, Jackson I, Sun K, Bouwman RD, Young RA, Glimcher LH, Lord GM. 2009. The transcription factors T-bet and GATA-3 control alternative pathways of T-cell differentiation through a shared set of target genes. Proc Natl Acad Sci 106: 17876-17881.

Johnston RJ, Poholek AC, DiToro D, Yusuf I, Eto D, Barnett B, Dent AL, Craft J, Crotty S. 2009. Bcl6 and Blimp-1 are reciprocal and antagonistic regulators of $\mathrm{T}$ follicular helper cell differentiation. Science 325: 1006-1010.
Johnston RJ, Choi YS, Diamond JA, Yang JA, Crotty S. 2012. STAT5 is a potent negative regulator of $\mathrm{T}_{\mathrm{FH}}$ cell differentiation. J Exp Med 209: 243-250.

Josefowicz SZ, Lu LF, Rudensky AY. 2012. Regulatory T cells: Mechanisms of differentiation and function. Annu Rev Immunol 30: 531-564.

Kagami S, Nakajima H, Kumano K, Suzuki K, Suto A, Imada K, Davey HW, Saito Y, Takatsu K, Leonard WJ, et al. 2000. Both Stat5a and Stat5b are required for antigen-induced eosinophil and T-cell recruitment into the tissue. Blood 95: 1370-1377.

Kagami S, Nakajima H, Suto A, Hirose K, Suzuki K, Morita S, Kato I, Saito Y, Kitamura T, Iwamoto I. 2001. Stat5a regulates $\mathrm{T}$ helper cell differentiation by several distinct mechanisms. Blood 97: 2358-2365.

Kanhere A, Hertweck A, Bhatia U, Gokmen MR, Perucha E, Jackson I, Lord GM, Jenner RG. 2012. T-bet and GATA3 orchestrate Th1 and Th2 differentiation through lineagespecific targeting of distal regulatory elements. Nat Commun 3: 1268.

Kaplan MH, Schindler U, Smiley ST, Grusby MJ. 1996a. Stat6 is required for mediating responses to IL-4 and for development of Th2 cells. Immunity 4: 313-319.

Kaplan MH, Sun YL, Hoey T, Grusby MJ. 1996b. Impaired IL-12 responses and enhanced development of Th2 cells in Stat4-deficient mice. Nature 382: 174-177.

Kim BS, Wang K, Siracusa MC, Saenz SA, Brestoff JR, Monticelli LA, Noti M, Tait Wojno ED, Fung TC, Kubo M, et al. 2014. Basophils promote innate lymphoid cell responses in inflamed skin. J Immunol 193: 3717-3725.

King IL, Mohrs M. 2009. IL-4-producing $\mathrm{CD}^{+}{ }^{+} \mathrm{T}$ cells in reactive lymph nodes during helminth infection are $\mathrm{T}$ follicular helper cells. J Exp Med 206: 1001-1007.

Klein Wolterink RG, Serafini N, van Nimwegen M, Vosshenrich CA, de Bruijn MJ, Fonseca Pereira D, Veiga Fernandes H, Hendriks RW, Di Santo JP. 2013. Essential, dose-dependent role for the transcription factor Gata3 in the development of IL-5 $5^{+}$and IL- $13^{+}$type 2 innate lymphoid cells. Proc Natl Acad Sci 110: 10240-10245.

Klose CS, Flach M, Mohle L, Rogell L, Hoyler T, Ebert K, Fabiunke C, Pfeifer D, Sexl V, Fonseca-Pereira D, et al. 2014. Differentiation of type 1 ILCs from a common progenitor to all helper-like innate lymphoid cell lineages. Cell 157: 340-356.

Koch MA, Tucker-Heard G, Perdue NR, Killebrew JR, Urdahl KB, Campbell DJ. 2009. The transcription factor Tbet controls regulatory $\mathrm{T}$ cell homeostasis and function during type 1 inflammation. Nat Immunol 10: 595-602.

Komatsu N, Mariotti-Ferrandiz ME, Wang Y, Malissen B, Waldmann H, Hori S. 2009. Heterogeneity of natural Foxp $3^{+} \mathrm{T}$ cells: A committed regulatory $\mathrm{T}$-cell lineage and an uncommitted minor population retaining plasticity. Proc Natl Acad Sci 106: 1903-1908.

Komatsu N, Okamoto K, Sawa S, Nakashima T, Oh-hora M, Kodama T, Tanaka S, Bluestone JA, Takayanagi H. 2014. Pathogenic conversion of Foxp $3^{+} \mathrm{T}$ cells into $\mathrm{T}_{\mathrm{H}} 17$ cells in autoimmune arthritis. Nat Med 20: 62-68.

Kopf M, Le Gros G, Bachmann M, Lamers MC, Bluethmann H, Kohler G. 1993. Disruption of the murine IL-4 gene blocks Th2 cytokine responses. Nature 362: 245-248. 
Korn T, Bettelli E, Oukka M, Kuchroo VK. 2009. IL-17 and Th17 cells. Annu Rev Immunol 27: 485-517.

Koues OI, Collins PL, Cella M, Robinette ML, Porter SI, Pyfrom SC, Payton JE, Colonna M, Oltz EM. 2016. Distinct gene regulatory pathways for human innate versus adaptive lymphoid cells. Cell 165: 1134-1146.

Kuperman DA, Huang X, Koth LL, Chang GH, Dolganov GM, Zhu Z, Elias JA, Sheppard D, Erle DJ. 2002. Direct effects of interleukin-13 on epithelial cells cause airway hyperreactivity and mucus overproduction in asthma. Nat Med 8: 885-889.

Kurata H, Lee HJ, O'Garra A, Arai N. 1999. Ectopic expression of activated Stat6 induces the expression of Th2-specific cytokines and transcription factors in developing Th1 cells. Immunity 11: 677-688.

Laurence A, Tato CM, Davidson TS, Kanno Y, Chen Z, Yao Z, Blank RB, Meylan F, Siegel R, Hennighausen L, et al. 2007. Interleukin-2 signaling via STAT5 constrains $\mathrm{T}$ helper 17 cell generation. Immunity 26: 371-381.

Lazarevic V, Chen X, Shim JH, Hwang ES, Jang E, Bolm AN, Oukka M, Kuchroo VK, Glimcher LH. 2011. T-bet represses $\mathrm{T}_{\mathrm{H}} 17$ differentiation by preventing Runx1-mediated activation of the gene encoding ROR $\gamma$ t. Nat Immunol 12: 96-104.

Lee YK, Turner H, Maynard CL, Oliver JR, Chen D, Elson CO, Weaver CT. 2009. Late developmental plasticity in the T helper 17 lineage. Immunity 30: 92-107.

Lee Y, Awasthi A, Yosef N, Quintana FJ, Xiao S, Peters A, Wu C, Kleinewietfeld M, Kunder S, Hafler DA, et al. 2012. Induction and molecular signature of pathogenic $\mathrm{T}_{\mathrm{H}} 17$ cells. Nat Immunol 13: 991-999.

Lexberg MH, Taubner A, Albrecht I, Lepenies I, Richter A, Kamradt T, Radbruch A, Chang HD. 2010. IFN- $\gamma$ and IL-12 synergize to convert in vivo generated Th17 into Th1/Th17 cells. Eur J Immunol 40: 3017-3027.

Liang SC, Tan XY, Luxenberg DP, Karim R, Dunussi-Joannopoulos K, Collins M, Fouser LA. 2006. Interleukin (IL)22 and IL-17 are coexpressed by Th17 cells and cooperatively enhance expression of antimicrobial peptides. J Exp Med 203: 2271-2279.

Liang HE, Reinhardt RL, Bando JK, Sullivan BM, Ho IC, Locksley RM. 2012. Divergent expression patterns of IL-4 and IL-13 define unique functions in allergic immunity. Nat Immunol 13: 58-66.

Liao W, Schones DE, Oh J, Cui Y, Cui K, Roh TY, Zhao K, Leonard WJ. 2008. Priming for T helper type 2 differentiation by interleukin 2-mediated induction of interleukin 4 receptor $\alpha$-chain expression. Nat Immunol 9: 1288 1296.

Liao W, Lin JX, Wang L, Li P, Leonard WJ. 2011. Modulation of cytokine receptors by IL-2 broadly regulates differentiation into helper T cell lineages. Nat Immunol 12: 551559.

Lighvani AA, Frucht DM, Jankovic D, Yamane H, Aliberti J, Hissong BD, Nguyen BV, Gadina M, Sher A, Paul WE, et al. 2001. T-bet is rapidly induced by interferon- $\gamma$ in lymphoid and myeloid cells. Proc Natl Acad Sci 98: 15137-15142.

Linterman MA, Pierson W, Lee SK, Kallies A, Kawamoto S, Rayner TF, Srivastava M, Divekar DP, Beaton L, Hogan JJ, et al. 2011. Foxp $3^{+}$follicular regulatory T cells control the germinal center response. Nat Med 17: 975-982.
Liu YJ. 2006. Thymic stromal lymphopoietin: Master switch for allergic inflammation. J Exp Med 203: 269-273.

Liu YJ, Soumelis V, Watanabe N, Ito T, Wang YH, Malefyt Rde W, Omori M, Zhou B, Ziegler SF. 2007. TSLP: An epithelial cell cytokine that regulates $\mathrm{T}$ cell differentiation by conditioning dendritic cell maturation. Annu Rev Immunol 25: 193-219.

Lu KT, Kanno Y, Cannons JL, Handon R, Bible P, Elkahloun AG, Anderson SM, Wei L, Sun H, O'Shea JJ, et al. 2011. Functional and epigenetic studies reveal multistep differentiation and plasticity of in vitro-generated and in vivoderived follicular T helper cells. Immunity 35: 622-632.

Luthje K, Kallies A, Shimohakamada Y, GT TB, Light A, Tarlinton DM, Nutt SL. 2012. The development and fate of follicular helper T cells defined by an IL-21 reporter mouse. Nat Immunol 13: 491-498.

Martin-Fontecha A, Thomsen LL, Brett S, Gerard C, Lipp M, Lanzavecchia A, Sallusto F. 2004. Induced recruitment of NK cells to lymph nodes provides IFN- $\gamma$ for $\mathrm{T}_{\mathrm{H}} 1$ priming. Nat Immunol 5: 1260-1265.

Mathur AN, Chang HC, Zisoulis DG, Kapur R, Belladonna ML, Kansas GS, Kaplan MH. 2006. T-bet is a critical determinant in the instability of the IL-17-secreting T-helper phenotype. Blood 108: 1595-1601.

McKinley L, Alcorn JF, Peterson A, Dupont RB, Kapadia S, Logar A, Henry A, Irvin CG, Piganelli JD, Ray A, et al. 2008. $\mathrm{T}_{\mathrm{H}} 17$ cells mediate steroid-resistant airway inflammation and airway hyperresponsiveness in mice. J Immunol 181: 4089-4097.

Min B, Prout M, Hu-Li J, Zhu J, Jankovic D, Morgan ES, Urban JF Jr, Dvorak AM, Finkelman FD, LeGros G, et al. 2004. Basophils produce IL-4 and accumulate in tissues after infection with a Th2-inducing parasite. J Exp Med 200: 507-517.

Mirchandani AS, Besnard AG, Yip E, Scott C, Bain CC, Cerovic V, Salmond RJ, Liew FY. 2014. Type 2 innate lymphoid cells drive $\mathrm{CD} 4{ }^{+} \mathrm{Th} 2$ cell responses. JImmunol 192: 2442-2448.

Mjosberg J, Bernink J, Golebski K, Karrich JJ, Peters CP, Blom B, te Velde AA, Fokkens WJ, van Drunen CM, Spits H. 2012. The transcription factor GATA3 is essential for the function of human type 2 innate lymphoid cells. Immunity 37: 649-659.

Monticelli LA, Sonnenberg GF, Abt MC, Alenghat T, Ziegler CG, Doering TA, Angelosanto JM, Laidlaw BJ, Yang CY, Sathaliyawala T, et al. 2011. Innate lymphoid cells promote lung-tissue homeostasis after infection with influenza virus. Nat Immunol 12: 1045-1054.

Moriggl R, Topham DJ, Teglund S, Sexl V, McKay C, Wang D, Hoffmeyer A, van Deursen J, Sangster MY, Bunting KD, et al. 1999. Stat5 is required for IL-2-induced cell cycle progression of peripheral $\mathrm{T}$ cells. Immunity 10: 249-259.

Moro K, Yamada T, Tanabe M, Takeuchi T, Ikawa T, Kawamoto H, Furusawa J, Ohtani M, Fujii H, Koyasu S. 2010. Innate production of $\mathrm{T}_{\mathrm{H}} 2$ cytokines by adipose tissueassociated c-Kit ${ }^{+} \mathrm{Sca}-1^{+}$lymphoid cells. Nature 463: 540-544.

Mosmann TR, Coffman RL. 1989. $\mathrm{T}_{\mathrm{H}} 1$ and $\mathrm{T}_{\mathrm{H}} 2$ cells: Different patterns of lymphokine secretion lead to different functional properties. Annu Rev Immunol 7: 145-173. 
Mosmann TR, Cherwinski H, Bond MW, Giedlin MA, Coffman RL. 1986. Two types of murine helper T cell clone. I: Definition according to profiles of lymphokine activities and secreted proteins. J Immunol 136: 2348 2357.

Mullen AC, High FA, Hutchins AS, Lee HW, Villarino AV, Livingston DM, Kung AL, Cereb N, Yao TP, Yang SY, et al 2001. Role of T-bet in commitment of $\mathrm{T}_{\mathrm{H}} 1$ cells before IL12-dependent selection. Science 292: 1907-1910.

Murphy KM, Reiner SL. 2002. The lineage decisions of helper T cells. Nat Rev 2: 933-944.

Nakayamada S, Kanno Y, Takahashi H, Jankovic D, Lu KT, Johnson TA, Sun HW, Vahedi G, Hakim O, Handon R, et al. 2011. Early Th1 cell differentiation is marked by a Tfh cell-like transition. Immunity 35: 919-931.

Neill DR, Wong SH, Bellosi A, Flynn RJ, Daly M, Langford TK, Bucks C, Kane CM, Fallon PG, Pannell R, et al. 2010. Nuocytes represent a new innate effector leukocyte that mediates type-2 immunity. Nature 464: 1367-1370.

Nelson RW, Beisang D, Tubo NJ, Dileepan T, Wiesner DL, Nielsen K, Wuthrich M, Klein BS, Kotov DI, Spanier JA, et al. 2014. T cell receptor cross-reactivity between similar foreign and self-peptides influences naive cell population size and autoimmunity. Immunity 42: 95-107.

Noval Rivas M, Burton OT, Wise P, Charbonnier LM, Georgiev P, Oettgen HC, Rachid R, Chatila TA. 2015. Regulatory $\mathrm{T}$ cell reprogramming toward a Th2-cell-like lineage impairs oral tolerance and promotes food allergy. Immunity 42: 512-523.

Nurieva RI, Chung Y, Hwang D, Yang XO, Kang HS, Ma L, Wang YH, Watowich SS, Jetten AM, Tian Q, et al. 2008. Generation of $\mathrm{T}$ follicular helper cells is mediated by interleukin-21 but independent of T helper 1, 2, or 17 cell lineages. Immunity 29: 138-149.

Nurieva RI, Chung Y, Martinez GJ, Yang XO, Tanaka S, Matskevitch TD, Wang YH, Dong C. 2009. Bcl6 mediates the development of T follicular helper cells. Science 325: 1001-1005.

Nurieva RI, Podd A, Chen Y, Alekseev AM, Yu M, Qi X, Huang H, Wen R, Wang J, Li HS, et al. 2012. STAT5 protein negatively regulates $\mathrm{T}$ follicular helper $(\mathrm{Tfh})$ cell generation and function. J Biol Chem 287: 11234-11239.

Oestreich KJ, Mohn SE, Weinmann AS. 2012. Molecular mechanisms that control the expression and activity of Bcl-6 in $\mathrm{T}_{\mathrm{H}} 1$ cells to regulate flexibility with a $\mathrm{T}_{\mathrm{FH}}$-like gene profile. Nat Immunol 13: 405-411.

Ohnmacht C, Park JH, Cording S, Wing JB, Atarashi K, Obata Y, Gaboriau-Routhiau V, Marques R, Dulauroy S, Fedoseeva M, et al. 2015. Mucosal immunology. The microbiota regulates type 2 immunity through $\mathrm{ROR} \gamma \mathrm{t}^{+}$ T cells. Science 349: 989-993.

Okada S, Markle JG, Deenick EK, Mele F, Averbuch D, Lagos M, Alzahrani M, Al-Muhsen S, Halwani R, Ma CS, et al. 2015. Immunodeficiencies. Impairment of immunity to Candida and Mycobacterium in humans with bi-allelic RORC mutations. Science 349: 606-613.

Oldenhove G, Bouladoux N, Wohlfert EA, Hall JA, Chou D, Dos Santos L, O'Brien S, Blank R, Lamb E, Natarajan S, et al. 2009. Decrease of Foxp3 ${ }^{+}$Treg cell number and acquisition of effector cell phenotype during lethal infection. Immunity 31: 772-786.
Oliphant CJ, Hwang YY, Walker JA, Salimi M, Wong SH, Brewer JM, Englezakis A, Barlow JL, Hams E, Scanlon ST, et al. 2014. MHCII-mediated dialog between group 2 innate lymphoid cells and $\mathrm{CD} 4^{+} \mathrm{T}$ cells potentiates type 2 immunity and promotes parasitic helminth expulsion. Immunity 41: 283-295.

Omori M, Ziegler S. 2007. Induction of IL-4 expression in $\mathrm{CD} 4^{+} \mathrm{T}$ cells by thymic stromal lymphopoietin. J Immunol 178: 1396-1404.

Oosterwegel MA, Mandelbrot DA, Boyd SD, Lorsbach RB, Jarrett DY, Abbas AK, Sharpe AH. 1999. The role of CTLA-4 in regulating Th2 differentiation. J Immunol 163: 2634-2639.

Ouyang W, Ranganath SH, Weindel K, Bhattacharya D, Murphy TL, Sha WC, Murphy KM. 1998. Inhibition of Th1 development mediated by GATA-3 through an IL-4independent mechanism. Immunity 9: 745-755.

Ouyang W, Lohning M, Gao Z, Assenmacher M, Ranganath S, Radbruch A, Murphy KM. 2000. Stat6-independent GATA-3 autoactivation directs IL-4-independent Th2 development and commitment. Immunity 12: 27-37.

Ouyang W, Kolls JK, Zheng Y. 2008. The biological functions of T helper 17 cell effector cytokines in inflammation. Immunity 28: 454-467.

Pai SY, Truitt ML, Ho IC. 2004. GATA-3 deficiency abrogates the development and maintenance of T helper type 2 cells. Proc Natl Acad Sci 101: 1993-1998.

Park H, Li Z, Yang XO, Chang SH, Nurieva R, Wang YH, Wang Y, Hood L, Zhu Z, Tian Q, et al. 2005. A distinct lineage of $\mathrm{CD} 4 \mathrm{~T}$ cells regulates tissue inflammation by producing interleukin 17. Nat Immunol 6: 1133-1141.

Paul WE, Seder RA. 1994. Lymphocyte responses and cytokines. Cell 76: 241-251.

Paul WE, Zhu J. 2010. How are $\mathrm{T}_{\mathrm{H}}$ 2-type immune responses initiated and amplified? Nat Rev 10: 225-235.

Peine M, Rausch S, Helmstetter C, Frohlich A, Hegazy AN, Kuhl AA, Grevelding CG, Hofer T, Hartmann S, Lohning M. 2013. Stable T-bet ${ }^{+}$GATA- $3^{+}$Th1/Th2 hybrid cells arise in vivo, can develop directly from naive precursors, and limit immunopathologic inflammation. PLoS Biol 11: e1001633.

Price AE, Liang HE, Sullivan BM, Reinhardt RL, Eisley CJ, Erle DJ, Locksley RM. 2010. Systemically dispersed innate IL-13-expressing cells in type 2 immunity. Proc Natl Acad Sci 107: 11489-11494.

Qiu J, Guo X, Chen ZM, He L, Sonnenberg GF, Artis D, Fu YX, Zhou L. 2013. Group 3 innate lymphoid cells inhibit T-cell-mediated intestinal inflammation through aryl hydrocarbon receptor signaling and regulation of microflora. Immunity 39: 386-399.

Reinhardt RL, Liang HE, Locksley RM. 2009. Cytokine-secreting follicular $\mathrm{T}$ cells shape the antibody repertoire. Nat Immunol 10: 385-393.

Rochman I, Watanabe N, Arima K, Liu YJ, Leonard WJ. 2007. Cutting edge: Direct action of thymic stromal lymphopoietin on activated human $\mathrm{CD}^{+} \mathrm{T}$ cells. J Immunol 178: 6720-6724.

Rochman Y, Spolski R, Leonard WJ. 2009. New insights into the regulation of T cells by $\gamma_{c}$ family cytokines. Nat Rev 9 : $480-490$. 
Roediger B, Kyle R, Yip KH, Sumaria N, Guy TV, Kim BS, Mitchell AJ, Tay SS, Jain R, Forbes-Blom E, et al. 2013. Cutaneous immunosurveillance and regulation of inflammation by group 2 innate lymphoid cells. Nat Immunol 14: $564-573$.

Rubtsov YP, Niec RE, Josefowicz S, Li L, Darce J, Mathis D, Benoist C, Rudensky AY. 2010. Stability of the regulatory T cell lineage in vivo. Science 329: 1667-1671.

Rudra D, deRoos P, Chaudhry A, Niec RE, Arvey A, Samstein RM, Leslie C, Shaffer SA, Goodlett DR, Rudensky AY. 2012. Transcription factor Foxp3 and its protein partners form a complex regulatory network. Nat Immunol 13: 1010-1019.

Sakaguchi S. 2004. Naturally arising $\mathrm{CD} 4^{+}$regulatory t cells for immunologic self-tolerance and negative control of immune responses. Annu Rev Immunol 22: 531-562.

Sakaguchi S, Miyara M, Costantino CM, Hafler DA. 2010 $\mathrm{FOXP}^{+}$regulatory $\mathrm{T}$ cells in the human immune system. Nat Rev 10: 490-500.

Sakaguchi S, Vignali DA, Rudensky AY, Niec RE, Waldmann H. 2013. The plasticity and stability of regulatory T cells. Nat Rev 13: 461-467.

Sano T, Huang W, Hall JA, Yang Y, Chen A, Gavzy SJ, Lee JY, Ziel JW, Miraldi ER, Domingos AI, et al. 2015. An IL23R/IL-22 circuit regulates epithelial serum amyloid A to promote local effector Th17 responses. Cell 163: 381-393.

Seder RA, Germain RN, Linsley PS, Paul WE. 1994. CD28mediated costimulation of interleukin 2 (IL-2) production plays a critical role in T cell priming for IL-4 and interferon $\gamma$ production. J Exp Med 179: 299-304.

Sefik E, Geva-Zatorsky N, Oh S, Konnikova L, Zemmour D, McGuire AM, Burzyn D, Ortiz-Lopez A, Lobera M, Yang J, et al. 2015. Mucosal immunology. Individual intestinal symbionts induce a distinct population of $\mathrm{ROR} \gamma^{+}$regulatory T cells. Science 349: 993-997.

Shevach EM. 2000. Regulatory T cells in autoimmmunity. Annu Rev Immunol 18: 423-449.

Shevach EM. 2009. Mechanisms of Foxp $3^{+}$T regulatory cellmediated suppression. Immunity 30: 636-645.

Shih HY, Sciume G, Mikami Y, Guo L, Sun HW, Brooks SR, Urban JF Jr, Davis FP, Kanno Y, O’Shea JJ. 2016. Developmental acquisition of regulomes underlies innate lymphoid cell functionality. Cell 165: 1120-1133.

Shimoda K, van Deursen J, Sangster MY, Sarawar SR, Carson RT, Tripp RA, Chu C, Quelle FW, Nosaka T, Vignali DA, et al. 1996. Lack of IL-4-induced Th2 response and IgE class switching in mice with disrupted Stat6 gene. Nature 380: 630-633.

Sokol CL, Barton GM, Farr AG, Medzhitov R. 2008. A mechanism for the initiation of allergen-induced $\mathrm{T}$ helper type 2 responses. Nat Immunol 9: 310-318.

Spits H, Bernink JH, Lanier L. 2016. NK cells and type 1 innate lymphoid cells: Partners in host defense. Nat Immunol 17: 758-764.

Steinfelder S, Andersen JF, Cannons JL, Feng CG, Joshi M, Dwyer D, Caspar P, Schwartzberg PL, Sher A, Jankovic D. 2009. The major component in schistosome eggs responsible for conditioning dendritic cells for Th2 polarization is a T2 ribonuclease (omega-1). J Exp Med 206: 16811690.
Stumbles PA, Thomas JA, Pimm CL, Lee PT, Venaille TJ Proksch S, Holt PG. 1998. Resting respiratory tract dendritic cells preferentially stimulate $\mathrm{T}$ helper cell type 2 (Th2) responses and require obligatory cytokine signals for induction of Th1 immunity. J Exp Med 188: 20192031.

Szabo SJ, Kim ST, Costa GL, Zhang XK, Fathman CG, Glimcher LH. 2000. A novel transcription factor, T-bet, directs Th1 lineage commitment. Cell 100: 655-669.

Szabo SJ, Sullivan BM, Stemmann C, Satoskar AR, Sleckman BP, Glimcher LH. 2002. Distinct effects of T-bet in $T_{H} 1$ lineage commitment and IFN- $\gamma$ production in CD4 and CD8 T cells. Science 295: 338-342.

Szabo SJ, Sullivan BM, Peng SL, Glimcher LH. 2003. Molecular mechanisms regulating Th1 immune responses. Annu Rev Immunol 21: 713-758.

Takeda K, Tanaka T, Shi W, Matsumoto M, Minami M, Kashiwamura S, Nakanishi K, Yoshida N, Kishimoto T, Akira S. 1996. Essential role of Stat6 in IL-4 signalling. Nature 380: 627-630.

Tanaka S, Motomura Y, Suzuki Y, Yagi R, Inoue H, Miyatake S, Kubo M. 2011. The enhancer HS2 critically regulates GATA-3-mediated Il4 transcription in $\mathrm{T}_{\mathrm{H}} 2$ cells. Nat Immunol 12: 77-85.

Tao X, Constant S, Jorritsma P, Bottomly K. 1997. Strength of TCR signal determines the costimulatory requirements for Th1 and Th2 $\mathrm{CD}^{+} \mathrm{T}$ cell differentiation. J Immunol 159: 5956-5963.

Thierfelder WE, van Deursen JM, Yamamoto K, Tripp RA, Sarawar SR, Carson RT, Sangster MY, Vignali DA, Doherty PC, Grosveld GC, et al. 1996. Requirement for Stat4 in interleukin-12-mediated responses of natural killer and T cells. Nature 382: 171-174.

Tubo NJ, Pagan AJ, Taylor JJ, Nelson RW, Linehan JL, Ertelt JM, Huseby ES, Way SS, Jenkins MK. 2013. Single naive $\mathrm{CD}^{+} \mathrm{T}$ cells from a diverse repertoire produce different effector cell types during infection. Cell 153: 785-796.

Urban JF Jr, Noben-Trauth N, Donaldson DD, Madden KB, Morris SC, Collins M, Finkelman FD. 1998. IL-13, IL- $4 \mathrm{R} \alpha$, and Stat 6 are required for the expulsion of the gastrointestinal nematode parasite Nippostrongylus brasiliensis. Immunity 8: 255-264.

Usui T, Nishikomori R, Kitani A, Strober W. 2003. GATA-3 suppresses Th1 development by downregulation of Stat 4 and not through effects on IL-12R $\beta 2$ chain or T-bet. Immunity 18: 415-428.

Usui T, Preiss JC, Kanno Y, Yao ZJ, Bream JH, O'Shea JJ, Strober W. 2006. T-bet regulates Th1 responses through essential effects on GATA-3 function rather than on IFNG gene acetylation and transcription. J Exp Med 203: 755766.

van Panhuys N, Tang SC, Prout M, Camberis M, Scarlett D, Roberts J, Hu-Li J, Paul WE, Le Gros G. 2008. In vivo studies fail to reveal a role for IL-4 or STAT6 signaling in Th2 lymphocyte differentiation. Proc Natl Acad Sci 105: 12423-12428.

van Panhuys N, Klauschen F, Germain RN. 2014. T-cellreceptor-dependent signal intensity dominantly controls $\mathrm{CD}^{+} \mathrm{T}$ cell polarization in vivo. Immunity 41: 63-74.

Veldhoen M, Hocking RJ, Atkins CJ, Locksley RM, Stockinger B. 2006. TGF $\beta$ in the context of an inflammatory 
J. Zhu

cytokine milieu supports de novo differentiation of IL-17producing T cells. Immunity 24: 179-189.

Vely F, Barlogis V, Vallentin B, Neven B, Piperoglou C, Ebbo M, Perchet T, Petit M, Yessaad N, Touzot F, et al. 2016. Evidence of innate lymphoid cell redundancy in humans. Nat Immunol 17: 1291-1299.

Voehringer D, Shinkai K, Locksley RM. 2004. Type $2 \mathrm{immu-}$ nity reflects orchestrated recruitment of cells committed to IL-4 production. Immunity 20: 267-277.

Wan YSY, Flavell RA. 2007. Regulatory T-cell functions are subverted and converted owing to attenuated Foxp3 expression. Nature 445: 766-770.

Wang YH, Voo KS, Liu B, Chen CY, Uygungil B, Spoede W, Bernstein JA, Huston DP, Liu YJ. 2010. A novel subset of $\mathrm{CD}^{+} \mathrm{T}_{\mathrm{H}} 2$ memory/effector cells that produce inflammatory IL-17 cytokine and promote the exacerbation of chronic allergic asthma. J Exp Med 207: 2479-2491.

Wang Y, Su MA, Wan YY. 2011. An essential role of the transcription factor GATA-3 for the function of regulatory T cells. Immunity 35: 337-348.

Wang Y, Misumi I, Gu AD, Curtis TA, Su L, Whitmire JK, Wan YY. 2013. GATA-3 controls the maintenance and proliferation of T cells downstream of TCR and cytokine signaling. Nat Immunol 14: 714-722.

Weaver CT, Hatton RD, Mangan PR, Harrington LE. 2007. IL-17 family cytokines and the expanding diversity of effector T cell lineages. Annu Rev Immunol 25: 821-852.

Wei G, Wei L, Zhu J, Zang C, Hu-Li J, Yao Z, Cui K, Kanno Y, Roh TY, Watford WT, et al. 2009. Global mapping of $\mathrm{H} 3 \mathrm{~K} 4 \mathrm{me} 3$ and $\mathrm{H} 3 \mathrm{~K} 27 \mathrm{me} 3$ reveals specificity and plasticity in lineage fate determination of differentiating $\mathrm{CD}^{+} \mathrm{T}$ cells. Immunity 30: 155-167.

Wei G, Abraham BJ, Yagi R, Jothi R, Cui K, Sharma S, Narlikar L, Northrup DL, Tang Q, Paul WE, et al. 2011. Genome-wide analyses of transcription factor GATA3mediated gene regulation in distinct $\mathrm{T}$ cell types. Immunity 35: 299-311.

Wohlfert EA, Grainger JR, Bouladoux N, Konkel JE, Oldenhove G, Ribeiro CH, Hall JA, Yagi R, Naik S, Bhairavabhotla $\mathrm{R}$, et al. 2011. GATA3 controls Foxp $3^{+}$regulatory $\mathrm{T}$ cell fate during inflammation in mice. J Clin Invest 121: 4503-4515.

Wynn TA. 2003. IL-13 effector functions. Annu Rev Immunol 21: 425-456.

Xu L, Kitani A, Fuss I, Strober W. 2007. Cutting edge: Regulatory $\mathrm{T}$ cells induce $\mathrm{CD} 4{ }^{+} \mathrm{CD} 25$-Foxp3- $\mathrm{T}$ cells or are self-induced to become Th17 cells in the absence of exogenous TGF- $\beta$. J Immunol 178: 6725-6729.

Yagi R, Junttila IS, Wei G, Urban JF Jr, Zhao K, Paul WE, Zhu J. 2010. The transcription factor GATA3 actively represses RUNX3 protein-regulated production of interferon- $\gamma$. Immunity 32: 507-517.

Yagi R, Zhu J, Paul WE. 2011. An updated view on transcription factor GATA3-mediated regulation of Th1 and Th2 cell differentiation. Int Immunol 23: 415-420.

Yagi R, Zhong C, Northrup DL, Yu F, Bouladoux N, Spencer S, Hu G, Barron L, Sharma S, Nakayama T, et al. 2014. The transcription factor GATA3 is critical for the development of all IL-7R $\alpha$-expressing innate lymphoid cells. Immunity 40: 378-388.
Yamaguchi T, Wing JB, Sakaguchi S. 2011. Two modes of immune suppression by Foxp $3^{+}$regulatory T cells under inflammatory or non-inflammatory conditions. Semin Immunol 23: 424-430.

Yamane H, Zhu J, Paul WE. 2005. Independent roles for IL-2 and GATA- 3 in stimulating naive $\mathrm{CD} 4^{+} \mathrm{T}$ cells to generate a Th2-inducing cytokine environment. J Exp Med 202: 793-804.

Yamashita M, Ukai-Tadenuma M, Kimura M, Omori M, Inami M, Taniguchi M, Nakayama T. 2002. Identification of a conserved GATA3 response element upstream proximal from the interleukin-13 gene locus. J Biol Chem 277: 42399-42408.

Yang Y, Ochando JC, Bromberg JS, Ding Y. 2007. Identification of a distant T-bet enhancer responsive to IL-12/ Stat 4 and IFN $\gamma /$ Stat1 signals. Blood 110: 2494-2500.

Yang XO, Nurieva R, Martinez GJ, Kang HS, Chung Y, Pappu BP, Shah B, Chang SH, Schluns KS, Watowich SS, et al. 2008. Molecular antagonism and plasticity of regulatory and inflammatory $\mathrm{T}$ cell programs. Immunity 29: $44-56$.

Yang XP, Ghoreschi K, Steward-Tharp SM, Rodriguez-Canales J, Zhu J, Grainger JR, Hirahara K, Sun HW, Wei L, Vahedi G, et al. 2011. Opposing regulation of the locus encoding IL-17 through direct, reciprocal actions of STAT3 and STAT5. Nat Immunol 12: 247-254.

Yang Q, Monticelli LA, Saenz SA, Chi AW, Sonnenberg GF, Tang J, De Obaldia ME, Bailis W, Bryson JL, Toscano K, et al. 2013. T cell factor 1 is required for group 2 innate lymphoid cell generation. Immunity 38: 694-704.

Yosef N, Shalek AK, Gaublomme JT, Jin H, Lee Y, Awasthi A, Wu C, Karwacz K, Xiao S, Jorgolli M, et al. 2013. Dynamic regulatory network controlling $\mathrm{T}_{\mathrm{H}} 17$ cell differentiation. Nature 496: 461-468.

Yu F, Sharma S, Edwards J, Feigenbaum L, Zhu J. 2015. Dynamic expression of transcription factors T-bet and GATA-3 by regulatory $\mathrm{T}$ cells maintains immunotolerance. Nat Immunol 16: 197-206.

Yusuf I, Kageyama R, Monticelli L, Johnston RJ, Ditoro D, Hansen K, Barnett B, Crotty S. 2010. Germinal center T follicular helper cell IL-4 production is dependent on signaling lymphocytic activation molecule receptor (CD150). J Immunol 185: 190-202.

Zaretsky AG, Taylor JJ, King IL, Marshall FA, Mohrs M, Pearce EJ. 2009. T follicular helper cells differentiate from Th2 cells in response to helminth antigens. J Exp Med 206: 991-999.

Zhang DH, Cohn L, Ray P, Bottomly K, Ray A. 1997. Transcription factor GATA-3 is differentially expressed in murine Th1 and Th2 cells and controls Th2-specific expression of the interleukin-5 gene. J Biol Chem 272: 21597-21603.

Zhang F, Meng G, Strober W. 2008. Interactions among the transcription factors Runx1, ROR $\gamma \mathrm{t}$ and Foxp3 regulate the differentiation of interleukin 17-producing $\mathrm{T}$ cells. Nat Immunol 9: 1297-1306.

Zheng W, Flavell RA. 1997. The transcription factor GATA3 is necessary and sufficient for Th2 cytokine gene expression in CD4 T cells. Cell 89: 587-596.

Zheng Y, Josefowicz SZ, Kas A, Chu TT, Gavin MA, Rudensky AY. 2007. Genome-wide analysis of Foxp3 target 
Th-Cell Differentiation and Plasticity

genes in developing and mature regulatory T cells. Nature 445: 936-940.

Zhong C, Cui K, Wilhelm C, Hu G, Mao K, Belkaid Y, Zhao K, Zhu J. 2016. Group 3 innate lymphoid cells continuously require the transcription factor GATA-3 after commitment. Nat Immunol 17: 169-178.

Zhou B, Comeau MR, De Smedt T, Liggitt HD, Dahl ME, Lewis DB, Gyarmati D, Aye T, Campbell DJ, Ziegler SF. 2005. Thymic stromal lymphopoietin as a key initiator of allergic airway inflammation in mice. Nat Immunol 6: 1047-1053.

Zhou L, Lopes JE, Chong MM, Ivanov II, Min R, Victora GD, Shen Y, Du J, Rubtsov YP, Rudensky AY, et al. 2008. TGF$\beta$-induced Foxp3 inhibits $\mathrm{T}_{\mathrm{H}} 17$ cell differentiation by antagonizing ROR $\gamma t$ function. Nature 453: 236-240.

Zhou L, Chong MM, Littman DR. 2009a. Plasticity of CD4 $4^{+}$ $\mathrm{T}$ cell lineage differentiation. Immunity 30: 646-655.

Zhou X, Bailey-Bucktrout SL, Jeker LT, Penaranda C, Martinez-Llordella M, Ashby M, Nakayama M, Rosenthal W, Bluestone JA. 2009b. Instability of the transcription factor Foxp3 leads to the generation of pathogenic memory $\mathrm{T}$ cells in vivo. Nat Immunol 10: 1000-1007.

Zhu J, Paul WE. 2008. CD4 T cells: Fates, functions, and faults. Blood 112: 1557-1569.

Zhu J, Paul WE. 2010a. Heterogeneity and plasticity of T helper cells. Cell research 20: 4-12.
Zhu J, Paul WE. 2010b. Peripheral CD4 ${ }^{+}$T-cell differentiation regulated by networks of cytokines and transcription factors. Immunol Rev 238: 247-262.

Zhu J, Guo L, Watson CJ, Hu-Li J, Paul WE. 2001. Stat6 is necessary and sufficient for IL-4's role in Th2 differentiation and cell expansion. J Immunol 166: 7276-7281.

Zhu J, Cote-Sierra J, Guo L, Paul WE. 2003. Stat5 activation plays a critical role in Th2 differentiation. Immunity 19: 739-748.

Zhu J, Min B, Hu-Li J, Watson CJ, Grinberg A, Wang Q, Killeen N, Urban JF Jr, Guo L, Paul WE. 2004. Conditional deletion of Gata3 shows its essential function in $\mathrm{T}_{\mathrm{H}} 1-\mathrm{T}_{\mathrm{H}} 2$ responses. Nat Immunol 5: 1157-1165.

Zhu J, Yamane H, Paul WE. 2010. Differentiation of effector CD4 T cell populations. Annu Rev Immunol 28: 445-489.

Zhu J, Jankovic D, Oler AJ, Wei G, Sharma S, Hu G, Guo L, Yagi R, Yamane H, Punkosdy G, et al. 2012. The transcription factor T-bet is induced by multiple pathways and prevents an endogenous Th2 cell program during Th1 cell responses. Immunity 37: 660-673.

Zielinski CE, Mele F, Aschenbrenner D, Jarrossay D, Ronchi F, Gattorno M, Monticelli S, Lanzavecchia A, Sallusto F. 2012. Pathogen-induced human $\mathrm{T}_{\mathrm{H}} 17$ cells produce IFN- $\gamma$ or IL-10 and are regulated by IL- $1 \beta$. Nature 484: 514-518. 


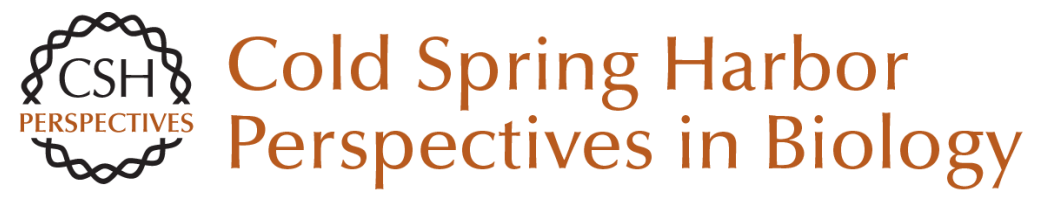

\section{T Helper Cell Differentiation, Heterogeneity, and Plasticity}

Jinfang Zhu

Cold Spring Harb Perspect Biol 2018; doi: 10.1101/cshperspect.a030338 originally published online August 28, 2017

\section{Subject Collection Cytokines}

Interleukin (IL)-33 and the IL-1 Family of Cytokines -Regulators of Inflammation and Tissue Homeostasis

Ajithkumar Vasanthakumar and Axel Kallies

Targeting IL-10 Family Cytokines for the Treatment of Human Diseases Xiaoting Wang, Kit Wong, Wenjun Ouyang, et al.

Cytokine-Mediated Regulation of CD8 T-Cell Responses During Acute and Chronic Viral Infection

Masao Hashimoto, Se Jin Im, Koichi Araki, et al.

Cytokines in Cancer Immunotherapy

Thomas A. Waldmann

The Tumor Necrosis Factor Family: Family Conventions and Private Idiosyncrasies David Wallach

The Interferon (IFN) Class of Cytokines and the IFN Regulatory Factor (IRF) Transcription Factor Family

Hideo Negishi, Tadatsugu Taniguchi and Hideyuki Yanai
Interferon $\gamma$ and Its Important Roles in Promoting and Inhibiting Spontaneous and Therapeutic Cancer Immunity

Elise Alspach, Danielle M. Lussier and Robert D. Schreiber

Inflammasome-Dependent Cytokines at the Crossroads of Health and Autoinflammatory Disease

Hanne Van Gorp, Nina Van Opdenbosch and Mohamed Lamkanfi

Innate Lymphoid Cells (ILCs): Cytokine Hubs Regulating Immunity and Tissue Homeostasis Maho Nagasawa, Hergen Spits and Xavier Romero Ros

T Helper Cell Differentiation, Heterogeneity, and

Plasticity Jinfang Zhu

Development, Diversity, and Function of Dendritic Cells in Mouse and Human

David A. Anderson III, Kenneth M. Murphy and Carlos G. Briseño

Cytokines and Long Noncoding RNAs Susan Carpenter and Katherine A. Fitzgerald

For additional articles in this collection, see http://cshperspectives.cshlp.org/cgi/collection/

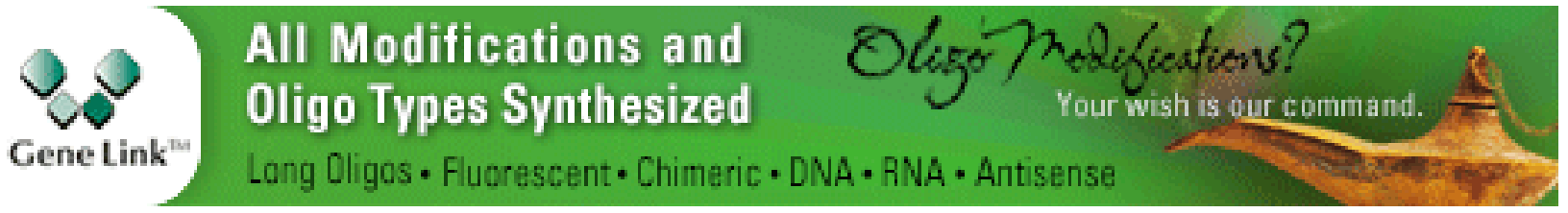

Copyright @ 2018 Cold Spring Harbor Laboratory Press; all rights reserved 
Role of the $\beta$ Common $(\beta \mathrm{c})$ Family of Cytokines in Health and Disease

Timothy R. Hercus, Winnie L. T. Kan, Sophie E. Broughton, et al.

Interleukin (IL)-12 and IL-23 and Their Conflicting Roles in Cancer Juming Yan, Mark J. Smyth and Michele W.L. Teng
Negative Regulation of Cytokine Signaling in Immunity

Akihiko Yoshimura, Minako Ito, Shunsuke Chikuma, et al.

Cancer Inflammation and Cytokines

Maria Rosaria Galdiero, Gianni Marone and Alberto Mantovani

For additional articles in this collection, see http://cshperspectives.cshlp.org/cgi/collection/

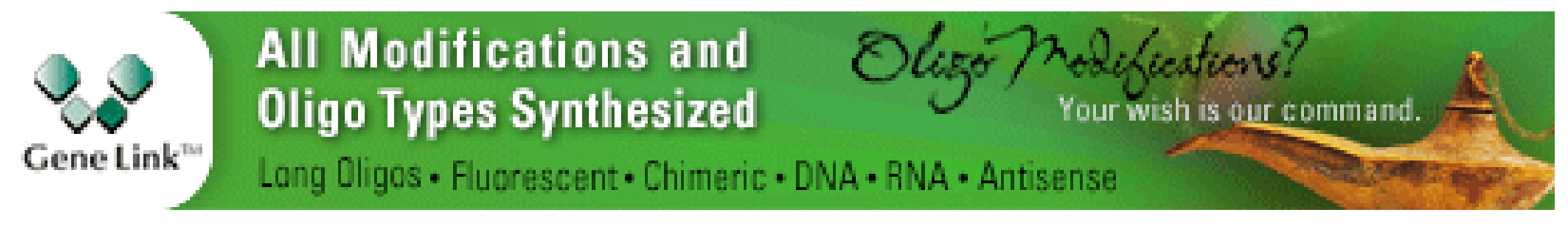

Copyright @ 2018 Cold Spring Harbor Laboratory Press; all rights reserved 